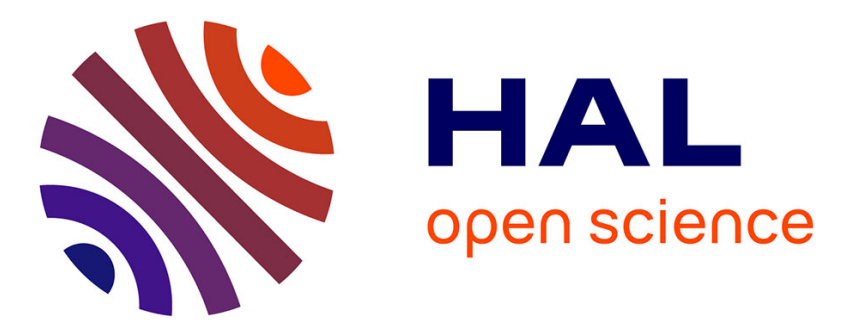

\title{
Modeling the fate of dietary phosphorus in the digestive tract of growing pigs
}

\author{
M.P. M.P. Létourneau-Montminy, Agnès Narcy, Philippe Lescoat, M. M. \\ Magnin, J.F. J. Bernier, Daniel Sauvant, Catherine C. Jondreville, C. C. \\ Pomar
}

\section{To cite this version:}

M.P. M.P. Létourneau-Montminy, Agnès Narcy, Philippe Lescoat, M. M. Magnin, J.F. J. Bernier, et al.. Modeling the fate of dietary phosphorus in the digestive tract of growing pigs. Journal of Animal Science, 2011, 89 (11), pp.3596-3611. 10.2527/jas.2010-3397 . hal-01000188

\section{HAL Id: hal-01000188 \\ https://hal.science/hal-01000188}

Submitted on 29 May 2020

HAL is a multi-disciplinary open access archive for the deposit and dissemination of scientific research documents, whether they are published or not. The documents may come from teaching and research institutions in France or abroad, or from public or private research centers.
L'archive ouverte pluridisciplinaire HAL, est destinée au dépôt et à la diffusion de documents scientifiques de niveau recherche, publiés ou non, émanant des établissements d'enseignement et de recherche français ou étrangers, des laboratoires publics ou privés. 


\section{JOURNAL OF ANIMAL SCIENCE \\ The Premier Journal and Leading Source of New Knowledge and Perspective in Animal Science}

Modeling the fate of dietary phosphorus in the digestive tract of growing pigs

M. P. Létourneau-Montminy, A. Narcy, P. Lescoat, M. Magnin, J. F. Bernier, D. Sauvant, C. Jondreville and C. Pomar

J ANIM SCI 2011, 89:3596-3611.

doi: 10.2527/jas.2010-3397 originally published online June 16, 2011

The online version of this article, along with updated information and services, is located on the World Wide Web at:

http://www.journalofanimalscience.org/content/89/11/3596

WWw.asas.org 


\title{
Modeling the fate of dietary phosphorus in the digestive tract of growing pigs ${ }^{1}$
}

\author{
M. P. Létourneau-Montminy, ${ }^{*}$ A. Narcy $\dagger \uparrow$ P. Lescoat, $\dagger$ M. Magnin,$\ddagger$ J. F. Bernier,$\S$ \\ D. Sauvant, \#\| C. Jondreville, $₫$ and C. Pomar*2
}

*Agriculture and Agri-Food Canada, Dairy and Swine Research and Development Center, Sherbrooke, Québec, J1M 1Z3, Canada; †INRA, UR83, F-37380 Nouzilly, France; $\ddagger$ BNA Nutrition Animale, F-53200 Château-Gontier, France; §Département des Sciences Animales, Université Laval, Quebec City, Québec, G1V 0A6, Canada; \#INRA, UMR791, F-75231 Paris, France; || AgroParisTech, UMR791, F-75231 Paris, France; and 9 INRA, Nancy-Université, USC 340 Animal et Fonctionnalités des Produits Animaux,

F-54500 Vandoeuvre-lès-Nancy, France

\begin{abstract}
Environmental effects of excess P from manure and the soaring price of phosphates are major issues in pig production. To optimize $\mathrm{P}$ utilization, it is crucial to improve our capacity to predict the amount of $\mathrm{P}$ absorbed, while taking into account the main factors of variation. Mathematical modeling can represent the complexity of the processes and interactions in determining the digestive utilization of $\mathrm{P}$ in growing pigs. This paper describes and evaluates a model developed to simulate the fate of the dietary forms of $\mathrm{P}$ in the digestive tract of growing pigs, with particular emphasis on the effect of dietary $\mathrm{Ca}$ and exogenous phytase on $\mathrm{P}$ digestive utilization. The model consists of $3 \mathrm{com}-$ partments associated with specific anatomical sections: stomach, proximal small intestine, and distal small intestine. The main metabolic processes occurring in these sections are, respectively, $\mathrm{P}$ solubilization/insolubilization and phytate $\mathrm{P}$ hydrolysis, and $\mathrm{P}$ absorption and $\mathrm{P}$ insolubilization. Model parameters governing these flows were derived from in vitro and in vivo literature data. The sensitivity analysis revealed that the model was stable within a large range of model parameter val-
\end{abstract}

ues $( \pm 1.5 \mathrm{SD})$. The model was able to predict the efficacy of Aspergillus niger microbial phytase in accordance with literature values, as well as the decreased efficacy of plant phytase compared with microbial phytase. The prediction capabilities of the model were assessed by comparing actual and simulated $\mathrm{P}$ and $\mathrm{Ca}$ apparent total-tract digestibility (ATTD) based on published pig data not used for model development. Prediction of $\mathrm{P}$ digestibility across 66 experiments and 281 observations was adequate $[\mathrm{P}$ ATTD observed $=0.24(\mathrm{SE}, 0.943)+$ $0.98(\mathrm{SE}, 0.0196) \times \mathrm{P}$ ATTD predicted; $\mathrm{R}^{2}, 0.90$; disturbance error (ED), 96.5\%], whereas prediction of Ca digestibility across 47 experiments and 193 observations was less accurate $(\mathrm{Ca}$ ATTD observed $=11.1+0.75$ $\times$ Ca ATTD predicted; $\mathrm{R}^{2}, 0.78 ; \mathrm{ED}, 20.4 \%$ ). A lack of agreement between experimental and simulated $\mathrm{Ca}$ digestibility was found. This model is, therefore, useful in evaluating $\mathrm{P}$ digestibility for different feedstuffs and feeding strategies. It can also be used to provide insight for improving dietary P utilization, especially from plant sources, by quantifying the effect of the mean sources of variation affecting $\mathrm{P}$ utilization.

Key words: calcium, digestion, mathematical model, phosphorus, phytase, pig

(C2011 American Society of Animal Science. All rights reserved.

J. Anim. Sci. 2011. 89:3596-3611

doi:10.2527/jas.2010-3397

\section{INTRODUCTION}

Phosphorus is an essential element for life. For animals, its absorption is mainly dependent on its supply

\footnotetext{
${ }^{1}$ The authors are grateful to J. van Milgen of INRA (Saint Gilles, France) and J. Sirois of Université de Sherbrooke (Sherbrooke, Québec, Canada) for their help in the development of this mathematical model.

${ }^{2}$ Corresponding author: Candido.Pomar@agr.gc.ca

Received August 5, 2010.

Accepted June 10, 2011.
}

form, which in plants is mostly phytate (Reddy et al., 1982). The availability of this form of $\mathrm{P}$ is reduced in nonruminant animals because they do not possess the phytase enzyme required to liberate this $\mathrm{P}$ in a form suitable for absorption, and thus a large portion of dietary $\mathrm{P}$ is excreted. The result could be nonpoint pollution, which is becoming increasingly worrisome (Correll, 1999). Additionally, after energy and protein, $\mathrm{P}$ is the most expensive nutrient in pig diets. Reducing the amount of dietary $\mathrm{P}$ given to pigs without negatively affecting their health or productivity is an essential issue for sustainable pig production systems. 
Optimizing dietary $\mathrm{P}$ utilization requires, notably, a good understanding of the fate of the ingested $\mathrm{P}$ in the digestive tract of the animal, taking into account its chemical form and interactions with factors such as phytase and dietary Ca. Indeed, given that phytase delivers $\mathrm{P}$ from phytate, this enzyme is currently added to pig diets and is often considered an alternative source of P (Selle and Ravindran, 2008). Moreover, although $\mathrm{Ca}$ is essential for bone mineralization and growth, dietary $\mathrm{Ca}$ is known to antagonize dietary $\mathrm{P}$ by forming insoluble, nonabsorbable complexes (Cheryan, 1980; Cromwell, 1996; Heaney and Nordin, 2002).

Mathematical modeling was chosen to represent and lead to better understanding of the complexity of $\mathrm{P}$ utilization by growing pigs. To date, a few models have simulated $\mathrm{P}$ and Ca metabolism in pigs (Besançon and Guéguen, 1969; Fernández, 1995b), although none of these addressed $\mathrm{P}$ digestive utilization in detail. The objective of the present study was, therefore, to develop and evaluate a dynamic, deterministic, and mechanistic research mathematical model that simulates the fate of dietary $\mathrm{P}$ in the digestive tract of growing pigs by integrating the most important physiological processes involved in $\mathrm{P}$ digestion and absorption.

\section{MATERIALS AND METHODS}

Animal Care and Use Committee approval was not obtained for this study because no animals were used.

\section{General Structure}

The model was developed with a compartmental structure that divides the digestive tract of pigs into 3 anatomical sections: the stomach (STO), the proximal part of the small intestine (PSI), and the distal part of the small intestine (DSI; Figure 1). Phytate P (PP) and nonphytate $\mathrm{P}$ (NPP) can be found in each compartment in their solubilized (PPs and NPPs) or nonsolubilized (PPns and NPPns) forms. Calcium from plant ingredients $(\mathbf{C a P l})$ is considered to enter the system solely in its nonsolubilized form (CaPlns), whereas Ca from mineral sources and animal ingredients is found in its solubilized (Cas) or nonsolubilized (Cans) form. Thus, 7 state variables in each compartment represent the different pools of $\mathrm{Ca}$ and $\mathrm{P}$. The model provides information about the flows of $\mathrm{P}$ and $\mathrm{Ca}$ across the gastrointestinal compartments, the amounts of these nutrients absorbed according to active and passive mechanisms, and the remaining amounts flowing to the large intestine.

State variables $(S)$ are expressed in grams, and time $(T)$ is expressed in minutes. Differential equations ( $\mathrm{d} S /$ $\mathrm{d} T$ ) describe the rate of change in the state variables with time. Rates $(R)$ represent the flow of materials between compartmental pools (solubilization, sol; insolubilization, insol; and hydrolysis, hydro) and between compartments (absorption, abs; passage, pa; and secretion, secr) and are expressed in grams per minute expect for variables related to $\mathrm{pH}$, which are expressed in moles per liter per minute. Auxiliary variables are noted by $A$ and constants by $K$. Simulation software (ModelMaker, version 4, Cherwell Scientific Ltd., Oxford, UK) was used for model development and simulation with an integration step of $1 \mathrm{~min}$. The model simulates dietary $\mathrm{P}$ and $\mathrm{Ca}$ digestive utilization in a 40-kg pig, the most frequent pig size used in the reviewed scientific literature. The model can be used for the whole growing period because the effect of the BW of the pig on $\mathrm{P}$ and Ca digestibility is low (Kemme et al., 1997; Létourneau-Montminy and Narcy, 2010). The results presented in this manuscript were obtained after 1,440 min of simulation to simulate daily results. All parameter abbreviations and descriptions are presented in Table 1.

\section{Parameterization}

The model was built with a mechanistic approach in which the underlying mechanisms were represented in the model. Parameter values were taken from in vitro or in vivo data and adjusted by regression techniques when necessary to fit experimental data. Literature data on $\mathrm{P}$ and $\mathrm{Ca}$ digestive utilization in growing pigs were compiled and organized into a database that was used for either model parameterization or model evaluation. The dietary nutrient composition was recalculated from the ingredient composition using the data provided by Sauvant et al. (2004).

\section{Characterization and Representation of Model Compartments}

The absorption of $\mathrm{P}$ and $\mathrm{Ca}$ is affected by the physicochemical conditions in the digestive tract of the pig, mainly luminal $\mathrm{pH}$. A low $\mathrm{pH}$ is required to ensure $\mathrm{P}$ and Ca solubilization, hydrolysis, and subsequent $\mathrm{P}$ and $\mathrm{Ca}$ absorption. Luminal $\mathrm{pH}$ also affects the ability of exogenous phytase to hydrolyze PP by acting on both phytate solubility and phytase activity. For these reasons, the gastrointestinal tract was divided into 3 sections, with each characterized by a specific luminal $\mathrm{pH}$. Intestinal sections were represented in the model as compartments.

Part of the ingested $\mathrm{Ca}$ and $\mathrm{P}$ is solubilized in the $\mathrm{STO}$, which is also the only compartment in which PP can be hydrolyzed by exogenous phytases because these enzymes are inactivated in the small intestine of the pig (Jongbloed et al., 1992; Rapp et al., 2001). The small intestine was divided into 2 segments of unequal size to account for the decreased efficiency of absorption of $\mathrm{P}$ and Ca (Moore and Tyler, 1955; Partridge, 1978). The first small intestine section is identified as the proximal part and is characterized by a low $\mathrm{pH}$, which allows most of the $\mathrm{P}$ and $\mathrm{Ca}$ to be maintained in their soluble forms (Pansu et al., 1984) and supports intense absorption. The $\mathrm{pH}$ increase in the DSI section induces the formation of insoluble complexes of $\mathrm{P}$ and $\mathrm{Ca}$ and the 


\section{a) Phosphorus}

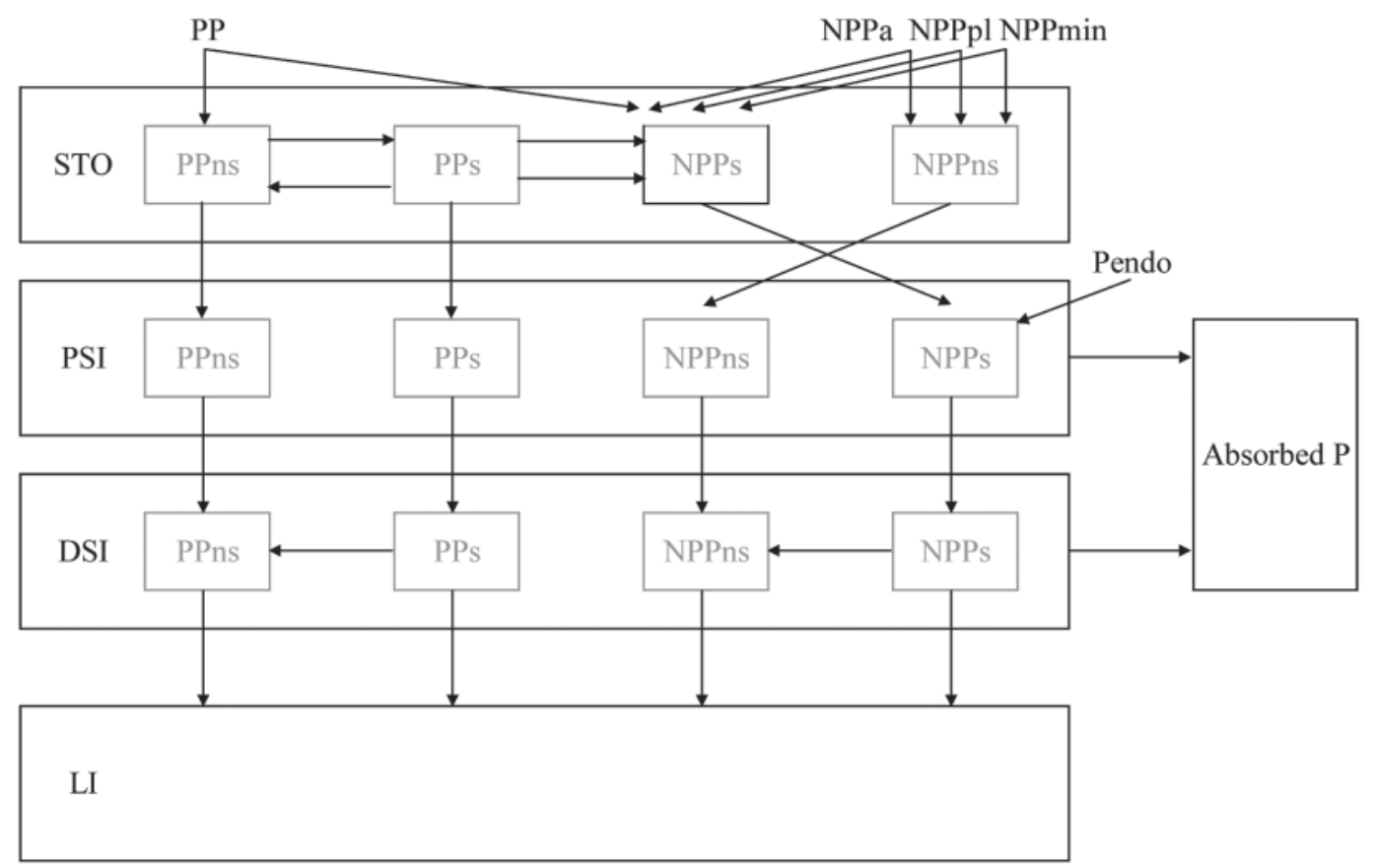

b) Calcium

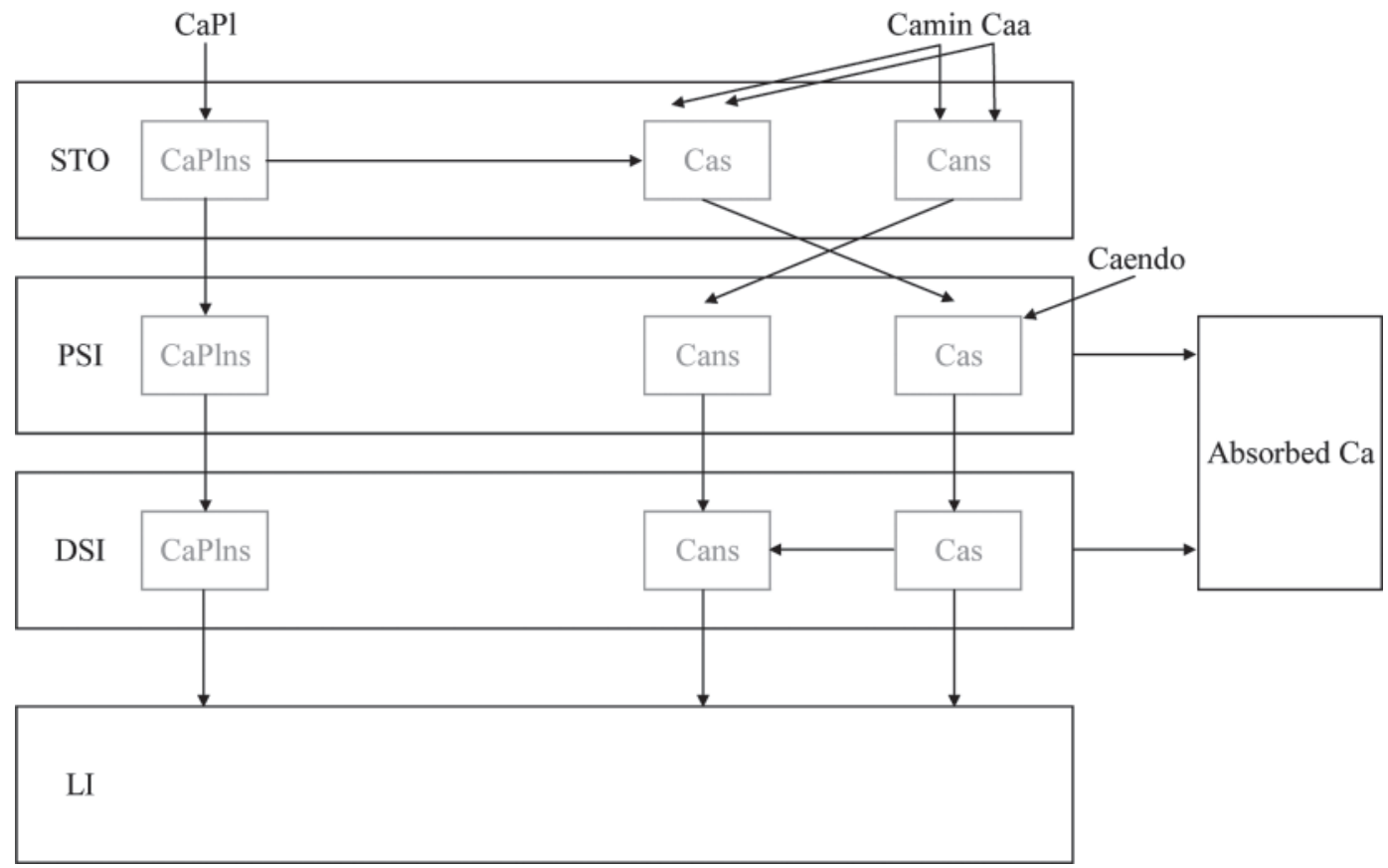

Figure 1. Phosphorus and Ca flows across the stomach (STO) and the proximal (PSI) and distal (DSI) anatomical sections of the small intestine as represented in the mathematical model. $\mathrm{LI}=$ large intestine. For $\mathrm{P}: \mathrm{PP}=$ phytate $\mathrm{P} ; \mathrm{NPPa}=$ nonphytate $\mathrm{P}$ of animal origin; $\mathrm{NPP} p=$ nonphytate $\mathrm{P}$ of plant origin; NPPmin $=$ nonphytate $\mathrm{P}$ of mineral origin; PPns $=$ nonsolubilized PP; PPs $=$ solubilized PP; NPPs $=$ solubilized $\mathrm{NPP}$; NPPns = nonsolubilized NPP; and Pendo = endogenous P. For Ca: CaPl = Ca of plant origin; Camin $=\mathrm{Ca}$ of mineral origin; Caa $=\mathrm{Ca}$ of animal origin; CaPlns $=$ nonsolubilized $\mathrm{CaPl}$; Cas $=$ solubilized $\mathrm{Ca}$; Cans $=$ nonsolubilized $\mathrm{Ca}$; Caendo = endogenous Ca.

reduction of mineral absorption. The PSI segment in the present model was approximately $2.5 \mathrm{~m}$ in length, which is in agreement with the estimates of Fox et al. (1977) and Partridge (1978). Assuming that the length of the small intestine of a 40-kg pig is $18 \mathrm{~m}$ (Laplace,
1970; Pommier et al., 1993), the DSI was $15.5 \mathrm{~m}$ in length.

$\boldsymbol{S T O}$. The STO inputs included qualitative and quantitative descriptions of the feed. Dietary P enters the system in its phytate or nonphytate form. It is as- 
Table 1. Abbreviation, description, value, and unit of the model parameters

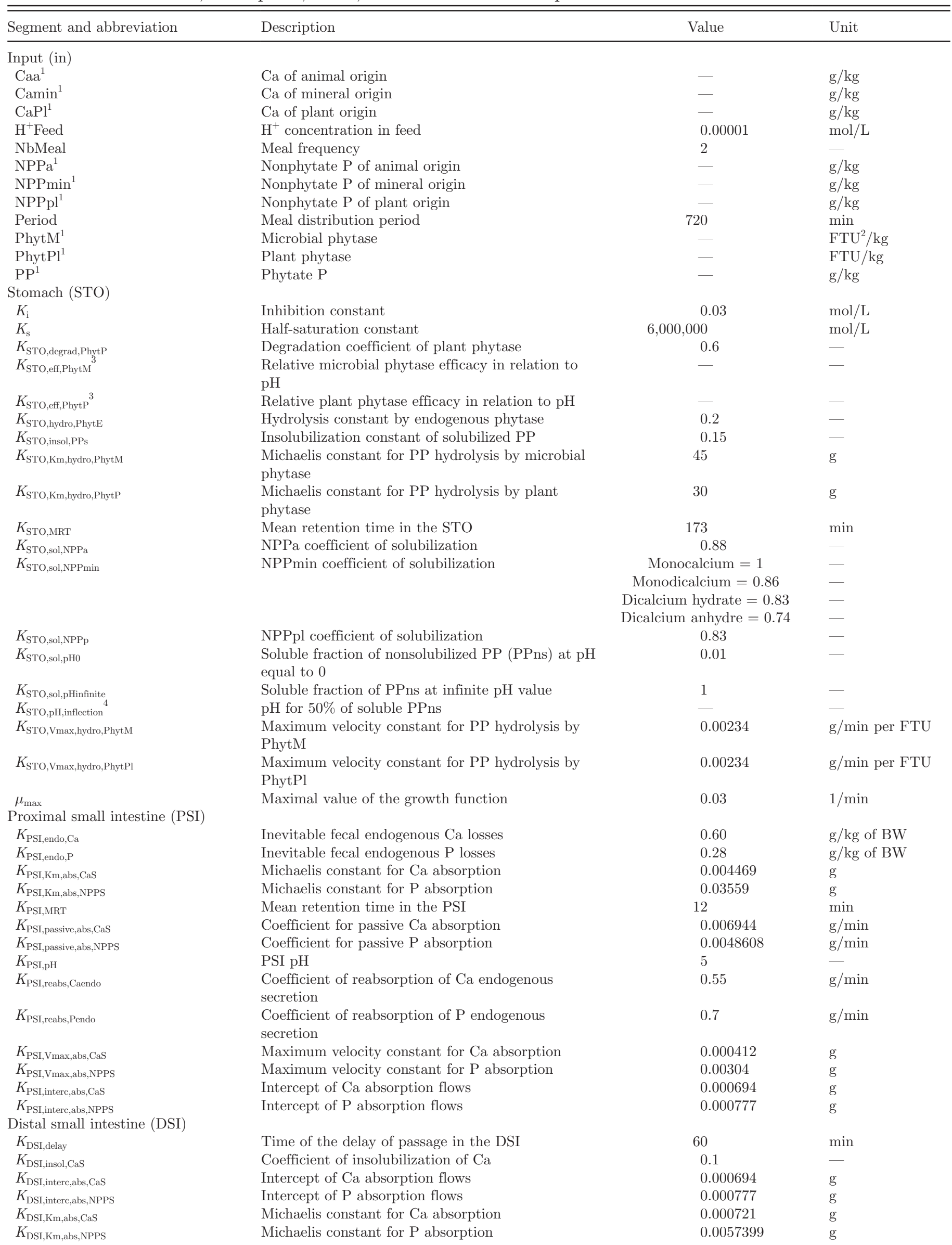


Table 1 (Continued). Abbreviation, description, value, and unit of the model parameters

\begin{tabular}{|c|c|c|c|}
\hline$K_{\mathrm{DSI}, \mathrm{MRT}}$ & Mean retention time in the DSI & 238 & $\min$ \\
\hline$K_{\text {DSI,nbmole,insol,CaS }}$ & Number of Cas in Ca-PP insoluble complexes & 3.0 & mol \\
\hline$K_{\mathrm{DSI}, \text { passive,abs,CaS }}$ & Coefficient for passive $\mathrm{Ca}$ absorption & 0.43056 & - \\
\hline$K_{\mathrm{DSI}, \mathrm{passive}, \text { abs,NPPS }}$ & Coefficient for passive $\mathrm{P}$ absorption & 0.30139 & - \\
\hline$K_{\mathrm{DSI}, \mathrm{Vmax}, \mathrm{abs}, \mathrm{NPPS}}$ & Maximum velocity constant for $\mathrm{P}$ absorption & 0.01886 & $\mathrm{~g} / \mathrm{min}$ \\
\hline MWCa & Molar weight of $\mathrm{Ca}$ & 40.08 & $\mathrm{~g} / \mathrm{mol}$ \\
\hline MWP & Molar weight of $\mathrm{P}$ & 30.97 & $\mathrm{~g} / \mathrm{mol}$ \\
\hline
\end{tabular}

${ }^{1}$ Values change according to diet and pig characteristics.

${ }^{2} \mathrm{FTU}=$ phytase unit.

${ }^{3}$ Information comes from Eeckhout and De Paepe (1992).

${ }^{4}$ Information comes from Pontoppidan et al. (2007).

sumed that all ingested PP is from plant materials, whereas NPP can be from plant, animal, or mineral (NPPmin) materials. Similarly, Ca can be provided by plant, mineral, or animal sources. Feed intake was modeled as a discontinuous process in which pigs eat 2 times a day at regular intervals. In fact, the objective was to simulate the fate of the dietary forms of $\mathrm{P}$ in the digestive tract of growing pigs when they are eating discrete meals. However, the number of meals does not have a real effect on the digestive fate of $\mathrm{P}$, at least when pigs eat discrete meals. The duration of the meal was not considered in the model because steady-state results of the model were used. The daily feed intake of a 40-kg pig was simulated according to van Milgen et al. (2008) using a power function of BW. The dietary inputs were calculated as the products of dietary $\mathrm{P}$ and Ca concentrations and feed intake. When present in the STO, PPns and CaPlns can be solubilized to PPs and solubilized plant $\mathrm{Ca}$, respectively, and PPs can be hydrolyzed by exogenous phytases to NPPs. These reactions are strongly affected by luminal $\mathrm{pH}$.

The amount of material transferred from the STO to the small intestine is proportional to the remaining material in the compartment (Cuber et al., 1981; Laplace et al., 1981; Gregory et al., 1990) and is represented by a first-order mass-action law, as suggested by Bastianelli et al. (1996), and estimated as the inverse of the mean retention time (MRT) as follows:

$$
R_{\mathrm{STO}, \mathrm{pa}, S}=K_{\mathrm{STO}, \mathrm{pa}, \mathrm{STO}-\mathrm{PSI}} \times S,
$$

where $R_{\mathrm{STO}, \mathrm{pa}, S}$ is the rate of passage of a state variable $S$ and $K_{\mathrm{STO}, \mathrm{pa}, \mathrm{STO}-\mathrm{PSI}}$ is a passage equal to $1 / \mathrm{MRT}$. This passage rate is assumed to apply to all forms of $\mathrm{Ca}$ and $\mathrm{P}$, with no distinction between solid and liquid phases. The MRT was set to 173 min (Cuber and Laplace, 1979; Rainbird and Low, 1986; Wilfart et al., 2007).

Stomach $\mathrm{pH}$ in fasting pigs is between 1 and 2 due to gastric secretion of $\mathrm{HCl}$ (Kidder and Manners, 1978). Gastric acid secretion is highly regulated to facilitate digestion. The overall goal of these regulations is to keep $\mathrm{pH}$ within a narrow range. After feeding, STO $\mathrm{pH}$ rapidly increases to 4 to 5 depending on the composition of the diet and the feed ingestion pattern (Kidder and Manners, 1978). The presence of feed in the STO induces distension and thus an increase in intragastric pressure that stimulates acid secretion, which peaks 90 to $150 \mathrm{~min}$ after the initiation of the meal (Noakes et al., 1968; Perez et al., 1986). Gastric secretion allows a gradual decrease in $\mathrm{pH}$ to its optimal level. In the model, the secretion of $\mathrm{H}^{+}$(mol) in the STO was simulated using a Haldane function, as proposed by Nuhoglu and Yalcin (2005),

$$
K_{\mathrm{STO}, \mathrm{secr}, \mathrm{H}^{+}}=\frac{\left(\mu_{\max } \times T\right)}{\left(T+K_{\mathrm{s}}+\frac{T^{2}}{K_{\mathrm{i}}}\right)},
$$

where $K_{\mathrm{STO}, \text { secr, } \mathrm{H}^{+}}$is the rate of $\mathrm{H}^{+}$secretion, $\mu_{\max }$ is the maximal growth rate, $K_{\mathrm{i}}$ is the inhibition constant, and $K_{\mathrm{s}}$ is the half-saturation constant defined as the concentration to which $\mu$ is equal to half $\mu_{\max }$. The kinetic constants of the Haldane function have been parameterized to represent the evolution of the observed $\mathrm{pH}$ $\left(-\log \mathrm{H}^{+}\right)$in the STO of pigs after a meal (Chiang et al., 2008).

The ingested PP enters the STO as PPns but is partly solubilized to PPs before being hydrolyzed in the presence of phytase (Taylor, 1965). Thereafter, part of the PPs is also insolubilized to PPns. The insolubilization rate of PPs $\left(R_{\mathrm{STO} \text {,insol,PPs }}\right)$ was simulated using the following equation:

$$
R_{\mathrm{STO}, \text { insol,PPs }}=K_{\mathrm{STO}, \text { insol,PPs }} \times \text { PPs. }
$$

The value of $K_{\mathrm{STO} \text {,insol.PPs }}$ was adjusted to account for the extent of PP hydrolysis reported in the literature. The rate of solubilization of PPns $\left(R_{\mathrm{STO}, \text { sol,PPns }}\right)$ is equal to $K_{\mathrm{STO}, \text { sol,PPns }} \times$ PPns, where $K_{\mathrm{STO}, \text { sol,PPns }}$ is related to both $K_{\mathrm{STO} \text {,insol,PPs }}$ and the soluble fraction of PP in the STO $\left(A_{\mathrm{STO}, \text { sol,PPns }}\right)$ using the following equation: 


$$
R_{\mathrm{STO}, \mathrm{sol}, \mathrm{PPns}}=\frac{\left(K_{\mathrm{STO}, \text { insol,PPs }} \times A_{\mathrm{STO}, \mathrm{sol}, \mathrm{PPns}}\right)}{\left(1-A_{\mathrm{STO}, \mathrm{sol}, \mathrm{PPns}}\right)} .
$$

The $A_{\mathrm{STO}, \text { sol,PPns }}$ was assumed to vary with $\mathrm{STO} \mathrm{pH}$ following a logistic representation that depends on 3 parameters, namely the fraction soluble at a $\mathrm{pH}$ of 0 $\left(K_{\mathrm{STO}, \text { sol, } \mathrm{pH} 0}\right)$, the fraction soluble at an infinite $\mathrm{pH}$ value $\left(K_{\mathrm{STO}, \text { sol.pHinfinite }}\right)$, and the inflection $\mathrm{pH}$ value where $50 \%$ of the PP is soluble $\left(K_{\mathrm{STO} \text {,pH,inflection }}\right)$, which depends of STO $\mathrm{pH}$. This model was represented as follows:

$$
\begin{aligned}
& A_{\mathrm{STO}, \mathrm{sol}, \mathrm{PP}}= \\
& \frac{\left(K_{\mathrm{STO}, \mathrm{sol}, \mathrm{pH} 0} \times K_{\mathrm{STO}, \mathrm{sol}, \mathrm{pHinfinite}}\right)}{\left[\begin{array}{l}
K_{\mathrm{STO}, \mathrm{sol}, \mathrm{pH} 0}+\left(K_{\mathrm{STO}, \mathrm{sol}, \mathrm{pHinfinite}}-K_{\mathrm{STO}, \mathrm{sol}, \mathrm{pH} 0}\right) \\
\times e^{-A_{\mathrm{STO}, \text { logparam }}} \times A_{\mathrm{STO}, \mathrm{pH}}
\end{array}\right]} \\
& A_{\mathrm{STO}, \text { logparam }}= \\
& \frac{\ln \left[\left(K_{\mathrm{STO}, \text { sol,pHinfinite }}-K_{\mathrm{STO}, \text { sol,pH0 }}\right) / K_{\mathrm{STO}, \mathrm{sol}, \mathrm{pH} 0}\right]}{K_{\mathrm{STO}, \mathrm{sol}, \mathrm{pH}, \text { inflection }}} .
\end{aligned}
$$

Phytate solubility is strongly affected by gastrointestinal $\mathrm{pH}$ and the concentration of divalent cations, notably $\mathrm{Ca}$ and proteins (Cheryan, 1980). At a pH range between 2 and 4 , there is a strong electrostatic interaction between protein and phytate that results in the formation of insoluble complexes, whereas at higher $\mathrm{pH}$ levels, phytate forms insoluble complexes with divalent cations. In the model, $A_{\mathrm{STO} \text {,logparam }}$ depends on $\mathrm{pH}$ and was parameterized according to the in vitro experiments conducted by Pontoppidan et al. (2007) using the values for realistic feed content of dietary Ca rather than the reduced values obtained without mineral supplementation. The approach used in the model to represent PP solubilization and insolubilization implies that, when phytase hydrolyzes part of the PPs, there is a relative shortage of soluble substrate, with the result that part of the PPns comes into solution as previously proposed by Kemme et al. (2006).

Part of the PPs can be hydrolyzed without exogenous phytase (Jongbloed et al., 1992; Rapp et al., 2001; Kemme et al., 2006), resulting in an apparent PP digestibility averaging 20\% (Létourneau-Montminy and Narcy, 2010) and, thus, an endogenous phytase hydrolysis constant ( $K_{\mathrm{STO} \text {,hydro,PhytE }}$, dimensionless) of 0.20 . The rate of PPs hydrolysis generated by microbial phytase (phytM) or plant phytase (phytPl) follows a Michaelis-Menten kinetic law. The hydrolysis of PP by phytM and phytPl was assumed to be additive in the model (Zimmermann et al., 2003). The maximum velocity $\left(\mathbf{V}_{\text {max }}\right)$ constant $\left(K_{\mathrm{STO}, \text { Vmax,phyt }}\right)$ of the Michaelis-Menten kinetic function law was estimated based on in vitro data (Ullah and Gibson, 1987; Kim et al., 2006; Weaver et al., 2009) for the phytase produced from $A s$ pergillus niger. The values of the affinity constants $\left(\boldsymbol{K}_{\mathrm{m}}\right)$ of phytM $\left(K_{\mathrm{STO}, \mathrm{Km}, \mathrm{phytM}}\right)$ and phytPl $\left(K_{\mathrm{STO}, \mathrm{Km}, \mathrm{phytPl}}\right)$ of the Michaelis-Menten function were obtained by fitting the data of PP hydrolysis in the STO in cannulated growing pigs fed diets with or without phytPl (wheat or barley) or phytM (A. niger; Jongbloed et al., 1992; Rapp et al., 2001; Kemme et al., 2006).

Microbial and plant phytases were also distinguished by their activity related to $\mathrm{pH}$. Efficacy coefficients ( $K_{\mathrm{STO}, \text { eff,PhytM }}$ and $K_{\mathrm{STO}, \text { eff,PhytPl}}$, dimensionless) were, thus, applied to the $\mathrm{V}_{\max }$ component ( $K_{\mathrm{STO} \text {,Vmax,phyt }}$ ) and its value depending on $\mathrm{pH}$ (Eeckhout and De Paepe, 1992). Moreover, it was previously shown both in vitro and in vivo that $A$. niger phytase was more stable than wheat phytase in the presence of protease (e.g., pepsin; Phillippy, 1999; Rapp et al., 2001). In accordance with those studies, a phytPl degradation constant ( $K_{\mathrm{STO} \text {,degrad,PhytPl }}$, dimensionless) of 0.60 was applied. The hydrolysis of PPs is then estimated as follows:

$$
\begin{aligned}
& R_{\mathrm{STO}, \text { hydro,PPs }}= \\
& \left(\mathrm{PPs} \times K_{\mathrm{STO}, \text { Vmax,phyt }} \times K_{\mathrm{STO}, \text { eff,PhytM }} \times \text { PhytM }\right) \\
& \left(\mathrm{PPs}+K_{\mathrm{STO}, \mathrm{Km}, \mathrm{PhytM}}\right) \\
& +\frac{\left(\begin{array}{l}
\text { PPs } \times K_{\mathrm{STO}, \text { Vmax }, \text { phyt }} \times K_{\mathrm{STO}, \text { eff,PhytP }} \\
\times K_{\mathrm{STO}, \text { degrad,PhytP }} \times \text { PhytP }
\end{array}\right.}{\left(\mathrm{PPs}+K_{\mathrm{STO}, \text { Km }, \text { PhytP }}\right)} .
\end{aligned}
$$

Many feed composition tables report differences in $\mathrm{P}$ digestibility among mineral $\mathrm{P}$ sources. To take that difference into account in the model, part of the dietary NPPmin enters at the beginning of the meal directly to the NPPs pool of the STO compartment, while the remaining part enters the NPPns pool according to a solubility coefficient $\left(K_{\mathrm{STO} \text {,sol,NPPmin }}\right.$, dimensionless $)$ defined for each dietary ingredient providing NPPmin (e.g., monocalcium phosphate, dicalcium phosphate). Solubility values were determined according to the apparent digestibility data of Jongbloed et al. (2002) by considering monocalcium phosphate as a reference ( $K_{\mathrm{STO}, \text { sol,NPPmin }}$ of 1$)$. The amount of NPPmin entering the NPPs pool was, thus, calculated as $K_{\mathrm{STO}, \text { sol,NPPmin }}$ $\times$ NPPmin, while the remaining NPPmin enters the NPPns pool. The solubility constant of NPP from animal materials was estimated according to the apparent digestibility coefficients assigned by Sauvant et al. (2004) to animal by-products, which are the major animal $\mathrm{P}$ sources used in pig diets. The digestibility of NPP from plant materials has never been directly assessed but was estimated at $73 \%$ based on a metaanalysis (Létourneau-Montminy and Narcy, 2010).

Concerning the fate of $\mathrm{Ca}$, part of the dietary CaPlns entering the STO is solubilized (to Cas). Most of the plant phytate contains 6 phosphate groups ( $K_{\mathrm{DSI}, \mathrm{nbmol}, \mathrm{PO} 4}$, mol; Pointillart, 1994) and can potentially bind up to 6 cations. Plant Ca was assumed to be totally linked to PP, as previously suggested by Ko- 
rnegay et al. (1996), given that the Ca:phytate molar ratio (mol:mol) in a corn- and soybean meal-based diet is approximately 3 (Sauvant et al., 2004). Consequently, CaPlns solubilization is related to the solubilization rate of PPns ( $\left.R_{\mathrm{STO}, \text { sol,CaPlns }}\right)$ as follows:

$$
\begin{aligned}
& R_{\mathrm{STO}, \text { sol,CaPns }}=\left(R_{\mathrm{STO}, \text { sol, }, \text { PPns }} / \mathrm{MWP}\right) \\
& \times A_{\mathrm{STO}, \mathrm{CaPIPP}} \times \mathrm{MWCa},
\end{aligned}
$$

where MWP is the molecular weight of $\mathrm{P}, A_{\mathrm{STO}, \mathrm{CaPIPP}}$ (mol:mol) is an auxiliary variable representing the ratio between dietary $\mathrm{CaPl}$ and $\mathrm{PP}$, and $\mathrm{MWCa}$ is the molecular weight of $\mathrm{Ca}$. Given the limited information on the availability of mineral Ca sources (Sauvant et al., 2004), it was assumed that all the Cas, including that from animal sources, was entirely solubilized ( $K_{\mathrm{STO}, \text { sol,Cans }}$ of 1$)$.

$\boldsymbol{P S I}$. In the PSI compartment, NPPs and Cas can be absorbed, whereas the other forms of $\mathrm{P}$ and $\mathrm{Ca}$ cannot be solubilized or hydrolyzed. Bile, pancreatic secretions in the duodenum, and desquamation of intestinal epithelial cells represent the major sources of endogenous $\mathrm{P}$ and Ca. Endogenous secretions are mixed with the chyme in the PSI. It was assumed that endogenous P and $\mathrm{Ca}$ enter exclusively in the PSI and are in a form suitable for absorption (Besançon and Guéguen, 1969; Fernández, 1995a), namely NPPs and Cas.

Because of the lack of information on the amounts of endogenous $\mathrm{P}$ and $\mathrm{Ca}$ secreted in the PSI, those values were estimated using experimental measurements of endogenous fecal losses and their intestinal absorptions. In pigs, endogenous $\mathrm{P}$ and $\mathrm{Ca}$ losses are generally considered proportional to BW (Guéguen and Perez, 1981; Rodehutscord et al., 1998; Jongbloed et al., 1999), although this assumption is not supported by all authors (Fernández, 1995a). Reported values range between 3 and $15 \mathrm{mg} / \mathrm{kg}$ of BW for P and between 6 and $30 \mathrm{mg} / \mathrm{kg}$ of BW for Ca (Guéguen and Perez, 1981; Jongbloed et al., 1999; Schulin-Zeuthen et al., 2007). Average values of $7 \mathrm{mg} / \mathrm{kg}$ of BW for P ( $K_{\text {PSI,endo,P }}$ ) and $15 \mathrm{mg} / \mathrm{kg}$ of $\mathrm{BW}$ for $\mathrm{Ca}\left(K_{\mathrm{PSI} \text {,endo,Ca }}\right)$ were chosen. Apparent digestibility coefficient values of 0.55 for $\mathrm{Ca}\left(K_{\mathrm{PSI}, \text { reabs,Caendo }}\right)$ and 0.70 for P ( $K_{\mathrm{PSI} \text {,reabs,Pendo; }}$ Guéguen and Perez, 1981) were used to estimate the secretions of these minerals. The rate of endogenous secretion $\left(R_{\mathrm{PSI}, \text { endo }}\right)$ was considered constant and was represented as follows:

$$
R_{\mathrm{PSI} \text {,endo }}=\frac{\left[\left(K_{\mathrm{PSI}, \text { endo }} \times \mathrm{BW}\right) /\left(1-K_{\mathrm{PSI}, \text { reabs,endo }}\right)\right]}{\mathrm{d} T} .
$$

The intestine is considered as a multicompartmental structure, as in the models of Bastianelli et al. (1996), Rivest et al. (2000), and Strathe et al. (2008). As assumed in the STO, the rate of passage is constant and equal to 1/MRT (Eq [1]). The progression of the chyme in the small intestine results from isolated local contractions and from contractions migrating upstream to downstream in the small intestine, namely the migrating myoelectric complexes (Code and Marlett, 1975). The decrease in speed of the migrating myoelectric complexes from the PSI to the DSI (30 vs. $5 \mathrm{~cm} / \mathrm{min}$; Laplace et al., 2001) induces a decrease in digesta transit speed. The equation established for the digestion model of Rivest et al. (2000) helps account for the variable transit time in the small intestine of pigs. With that equation, the average MRT in the PSI segment is estimated to be 12 min.

The gastric acidity is gradually buffered, especially by pancreatic and bile juices, and the $\mathrm{pH}$ of the chyme rises as feed moves through the small intestine. Values of $\mathrm{pH}$ of 5.0,6.0, and 7.3 in the duodenum, jejunum, and ileum, respectively, of pigs after a meal have been reported (Braude et al., 1976). For simplicity, the pH of the PSI section is considered constant. This intestinal section is the area in which intense absorption of Ca and $\mathrm{P}$ occurs and, thus, $\mathrm{pH}$ was set to 5 , ensuring that $\mathrm{P}$ and $\mathrm{Ca}$ were kept in their absorbable forms.

The absorption of $\mathrm{P}$ from the small intestine in pigs involves mostly active transport mechanisms, whereas the intestinal absorption of $\mathrm{Ca}$ results from a combination of active and passive flows (Fox et al., 1978). Thus, the absorption of $\mathrm{P}$ and $\mathrm{Ca}$ in the small intestine $\left(R_{\mathrm{SI}, \mathrm{abs}}\right)$ was modeled as follows:

$$
R_{\mathrm{S}, \mathrm{abs}}=\frac{K_{\mathrm{SI}, \text { inter,abs }}+\left(K_{\mathrm{SI}, \mathrm{Vmax}, \mathrm{abs}} \times[s]\right)}{\left(K_{\mathrm{SI}, \mathrm{Km}, \mathrm{abs}}+[s]\right)+\left(K_{\mathrm{SI}, \text { passive,abs }} \times[s]\right)},
$$

where $K_{\mathrm{SI}, \text { inter,abs }}$ is the intercept representing the absorption of endogenous $\mathrm{P}$ and $\mathrm{Ca}, K_{\mathrm{SI}, \mathrm{Vmax} \text {,abs }}$ is the $\mathrm{V}_{\max }$ constant, $[s]$ is the amount of substrate, $K_{\mathrm{SI}, \mathrm{Km} \text {,abs }}$ is the $\mathrm{K}_{\mathrm{m}}$, and $K_{\mathrm{SI} \text {,passive,abs }}$ is the coefficient of passive absorption. Parameters of $\mathrm{P}$ and $\mathrm{Ca}$ absorption were estimated by the NLIN procedure (SAS Inst. Inc., Cary, NC) based on the apparent absorption measured by Stein et al. (2008), using gradual content of monocalcium phosphate in a corn- and soybean meal-based diet in $30-\mathrm{kg}$ pigs. The parameters obtained were then adjusted to take into account the length of the compartment (PSI and DSI).

DSI. The NPPs and Cas substrates can also be absorbed in the DSI. However, because of the increase in luminal $\mathrm{pH}$ in this intestinal section, NPPs and Cas are partly insolubilized by being transformed into the NPPns and Cans forms, respectively. The only inputs of $\mathrm{P}$ and $\mathrm{Ca}$ in this compartment are those from the PSI. The MRT in 50-kg pigs with an average small intestine length of $18 \mathrm{~m}$ is $250 \mathrm{~min}$ (Rivest et al., 2000), which represents an MRT in the DSI of 238 min, considering the 12 min attributed to the proximal section. A delay function providing a lag time of $60 \mathrm{~min}$ (Darcy et al., 1980) for the passage of the digesta between the PSI and DSI compartments was included to prevent instant passage of material between compartments (Bastianelli et al., 1996; Strathe et al., 2008). The pH of the 
DSI was set to 7 (Moore and Tyler, 1955; Braude et al., 1976).

The absorption of $\mathrm{P}$ and $\mathrm{Ca}$ was represented as for the PSI and was parameterized from the data of Stein et al. (2008). In fact, phytic acid can act as a Ca-binding agent under the $\mathrm{pH}$ conditions in the DSI (Graf, 1983), and it was accordingly assumed that $1 \mathrm{~mol}$ of PP binds up to $3 \mathrm{~mol}$ of $\mathrm{Ca}\left(K_{\mathrm{DSI}, \mathrm{nbmol}, \text { insol,CaS }}\right)$. Therefore, PPs and Cas are insolubilized to, respectively, PPns and Cans forms in proportion to the level of PPs. Calcium can also bind phosphates and form insoluble complexes under these $\mathrm{pH}$ conditions (Heaney and Nordin, 2002), resulting in reduced amounts of $\mathrm{Ca}$ and $\mathrm{P}$ available for absorption. The formation of complexes was simulated according to the relative distribution of the form of inorganic phosphate and $\mathrm{pH}$ (van den Bossche, 1999). Under these $\mathrm{pH}$ conditions, both $\mathrm{H}_{2} \mathrm{PO}^{4-}$ and $\mathrm{HPO}_{4}{ }^{2-}$ are found in equal proportions. Thus, $1.5 \mathrm{~mol}$ of $\mathrm{P}$ ( $K_{\text {DSI,nbmol,insol,NPPs }}$, mol) can bind up to $1.0 \mathrm{~mol}$ of Ca. A maximum of $10 \%$ Cas can form insoluble complexes ( $K_{\mathrm{DSI}, \text { insol,NPPs }}$ ), a value that was set by fitting the effect of dietary Ca concentrations on $\mathrm{P}$ digestibility based on in vivo data (Larsen and Sandström, 1993; Lantzsch et al., 1995; Qian et al., 1996; Liu et al., 1998). The insolubilization of $\mathrm{P}$ and $\mathrm{Ca}$ were represented in the model as follows:

$$
\begin{aligned}
& K_{\mathrm{DSI}, \text { insol,NPPs }}=\frac{\left(K_{\mathrm{DSI}, \mathrm{insol}, \mathrm{NPPs}} \times R_{\mathrm{DSI}, \mathrm{pa}, \mathrm{PSI}-\mathrm{DSI}, \mathrm{Cas}}\right)}{\mathrm{MWCa}} \\
& \times\left(\mathrm{MWP} \times K_{\mathrm{DSI}, \mathrm{nbmol}, \mathrm{insol}, \mathrm{NPPs}}\right), \\
& K_{\mathrm{DSI}, \mathrm{insol}, \mathrm{Cas}}=\left(\frac{R_{\mathrm{DSI}, \mathrm{pa}, \mathrm{PSI}-\mathrm{DSI}, \mathrm{PPns}}+R_{\mathrm{DSI}, \mathrm{pa}, \mathrm{PSI}-\mathrm{DSI}, \mathrm{PP} \mathrm{s}}}{\mathrm{MWP}}\right) \\
& \times\left(\frac{K_{\mathrm{DSI}, \mathrm{nbmol}, \text { insol,Cas }} / K_{\mathrm{DSI}, \mathrm{nbmol}, \mathrm{PO} 4}}{\mathrm{MWCa}}\right) \\
& +\left(\frac{R_{\mathrm{DSI}, \text { insol,NPPs }} / \mathrm{MWP}}{K_{D \mathrm{SI}, \mathrm{nbmol} \text {,insol,NPPs }}}\right) \times \mathrm{MWCa} .
\end{aligned}
$$

\section{Model Evaluation}

The structure of the model and its mathematical and logical consistencies were checked throughout its development. The mathematical stability of the model was also assessed. The model was thereafter evaluated against its objectives (i.e., the development of a mechanistic mathematical model that integrates the main physiological processes involved in $\mathrm{P}$ digestion and absorption and the identification of the most important factors involved in the fate of $\mathrm{P}$ in the digestive tract of the growing-finishing pig). The most relevant model mechanisms and outputs were evaluated by simulating experimental situations and comparing the predictions of the model with the observed data. Literature data used for model development and parameterization were not included in this section.
A conventional univariate sensitivity analysis was performed by iteratively varying major input variables according to the SD reported in the literature, while keeping all other input variables at their central value to determine the critical areas in the system and highlight the most influential factors implicated in $\mathrm{P}$ and $\mathrm{Ca}$ digestive utilization. The calculated univariate sensitivity indexes are expressed relative to the original values to allow a direct evaluation of the magnitude of the deviation. The interaction between input variables was not investigated. The analysis was performed first in the STO, in which the sensitivity of the amount of PP hydrolyzed by phytase during the first hour after the meal was assessed in relation to the hydrolysis flow, the digesta transit rate, and $\mathrm{pH}$. Model parameters could then be ranked in relation to their effect on the apparent total-tract digestibility (ATTD) of $\mathrm{P}$ and Ca. When transit and absorption parameters were studied, the corresponding parameters for PSI and DSI were modified simultaneously in the same proportion. A corn- and soybean meal-based diet supplemented with phytM was used as the reference diet.

Sensitivity analysis was followed by a 2 -step evaluation analysis. First, to ensure that model daily outputs were in the range of normal responses as reported in the literature, an evaluation analysis was performed by simulating the digestion of several experimental diets and comparing predicted and observed apparent digestibility coefficient values. This external evaluation was performed using the ATTD of $\mathrm{P}$ and $\mathrm{Ca}$ as response criteria, which was obtained from literature data reported in 55 publications totaling 66 experiments and 281 treatments applied to growing pigs with an average BW of $32.7 \pm 17.3 \mathrm{~kg}$. These data had not been previously used to estimate parameters or calibrate the model. Direct comparisons between model and experimental parameters are not relevant given the increased interexperiment variability, which is much greater than the variability observed within a single experiment (Sauvant et al., 2005). The between-experiment variations include differences in analytical methods, pig BW, genetics, environmental growth conditions, and experimental design. A model including the experiment as a fixed effect was therefore used (Offner and Sauvant, 2004) in the GLM procedure (Minitab Inc., State College, PA) to estimate the ATTDm adjusted for the trial effect, as proposed by Sauvant et al. (2008):

$$
\operatorname{ATTDm}_{i j}=\alpha+\alpha_{i}+\left(B+\beta_{i}\right) \times \operatorname{ATTDp}_{i j}+\varepsilon_{i j},
$$

where $\operatorname{ATTDm}_{i j}$ is the ATTD coefficient measured in the publication, $\mathrm{ATTDp}_{i j}$ is the ATTD coefficient predicted by the proposed simulation model for experiment $i$ and treatment $j, \alpha$ is the intercept, $\alpha_{i}$ is the fixed effect of the trial on the intercept with the condition that the sum of each $\alpha_{i}$ is equal to $0, B$ is the slope of the regression, $\beta_{i}$ is the trial effect on the slope of the regression with the condition that the sum of each $\beta_{i}$ is equal to 0 , and $\varepsilon_{i j}$ is the residual error. The ability of the proposed 
Table 2. Univariate sensitivity indexes for phytate $\mathrm{P}$ hydrolysis in the stomach ${ }^{1}$

\begin{tabular}{lccccc}
\hline \hline & \multicolumn{5}{c}{ Variation, SD } \\
\cline { 2 - 6 } Kinetic parameter & -1.5 & -0.5 & 0 & 0.5 & 1.5 \\
\hline$K_{\mathrm{STO}, \mathrm{pH}}$ & 1.05 & 1.06 & 1.00 & 0.81 & 0.58 \\
$K_{\mathrm{STO}, \mathrm{Km}, \text { hydro }}$ & 1.52 & 1.17 & 1.00 & 0.87 & 0.74 \\
$K_{\mathrm{STO}, \mathrm{Vmax}, \text { hydro }}$ & 0.63 & 0.85 & 1.00 & 1.14 & 1.33 \\
$K_{\mathrm{STO}, \mathrm{pa}, \mathrm{STO}-\mathrm{PSI}}$ & 1.15 & 1.06 & 1.00 & 0.95 & 0.88 \\
\hline${ }^{1} K_{\mathrm{STO}, \mathrm{pH}}=\mathrm{pH}$ in the stomach; $K_{\mathrm{STO}, \text { Km,hydro }}=$ affinity constant of phytase; $K_{\mathrm{STO}, \text { Vmax,hydro }}=$ maximum velocity \\
constant of phytase; and $K_{\mathrm{STO}, \text { pa,STO-PSI }}=$ rate of transit in the stomach.
\end{tabular}

simulation model to reproduce the experimental conditions was evaluated based on the statistical properties of the intercept, the slope, the residual $\mathrm{SD}$, and the $\mathrm{R}^{2}$ obtained by regression between observed and predicted values. Additionally, the prediction error was assessed using the mean square prediction error (MSPE) with SAS. The MSPE was broken down into error in central tendency (ECT), error due to regression (ER), and error due to disturbance (ED), as used by Pomar and Marcoux (2005) according to Theil (1966) and Bibby and Toutenburg (1977). The ECT indicates how the average of predicted ATTD deviates from the average of observed ATTD. The ER measures the deviation of the least squares regression coefficient from one, the value that it would be if the predictions were completely accurate. The ED is the variation in the observed values that is not accounted for by a least squares regression of observed on predicted values. This error is, in fact, the unexplained variance and represents the portion of MSPE that cannot be eliminated by linear corrections of the predictions (Theil, 1966) and adjustment for experiment effect (Sauvant et al., 2008). Finally, root MSPE expressed as a percentage of the observed mean was also used as a measure of the prediction error. In the second evaluation analysis, the general model be- havior was studied by simulating specific dietary situations to evaluate the ability of the model to adequately represent critical aspects of $\mathrm{P}$ and $\mathrm{Ca}$ metabolism. The results of these simulations are the logical consequences and mathematical representations of the hypotheses included in the model.

\section{RESULTS}

\section{Sensitivity Analysis}

The hydrolysis of PP in the STO during the first hour after a meal was highly sensitive to the increase in $\mathrm{pH}$ in this compartment (i.e., $-42 \%$ for $+1.5 \mathrm{SD}$ ), whereas a decrease in $\mathrm{pH}$ had less of an effect (Table 2). The amount of PP hydrolyzed was also highly sensitive to the $\mathrm{V}_{\max }\left(K_{\mathrm{STO}, \text { Vmax,hydro }}\right)$ and $K_{\mathrm{m}}\left(K_{\mathrm{STO}, \text { Km,hydro }}\right)$ of phytase. The rate of STO evacuation (transit; $K_{\mathrm{STO}, \mathrm{pa}, \mathrm{STO}}$ PSI) also determined the fate of PP in the STO, because that rate regulates the extent of the contact between the enzyme and its substrate, although to a lesser extent than enzyme kinetic parameters.

The magnitude of the effects of varying STO parameters was less on P ATTD than on PP hydrolysis flow (i.e., 11 vs. $52 \%$, respectively, for a $-1.5 \mathrm{SD}$ variation

Table 3. Univariate sensitivity indexes for the apparent total-tract digestibility of $\mathrm{P}$ and $\mathrm{Ca}^{1}$

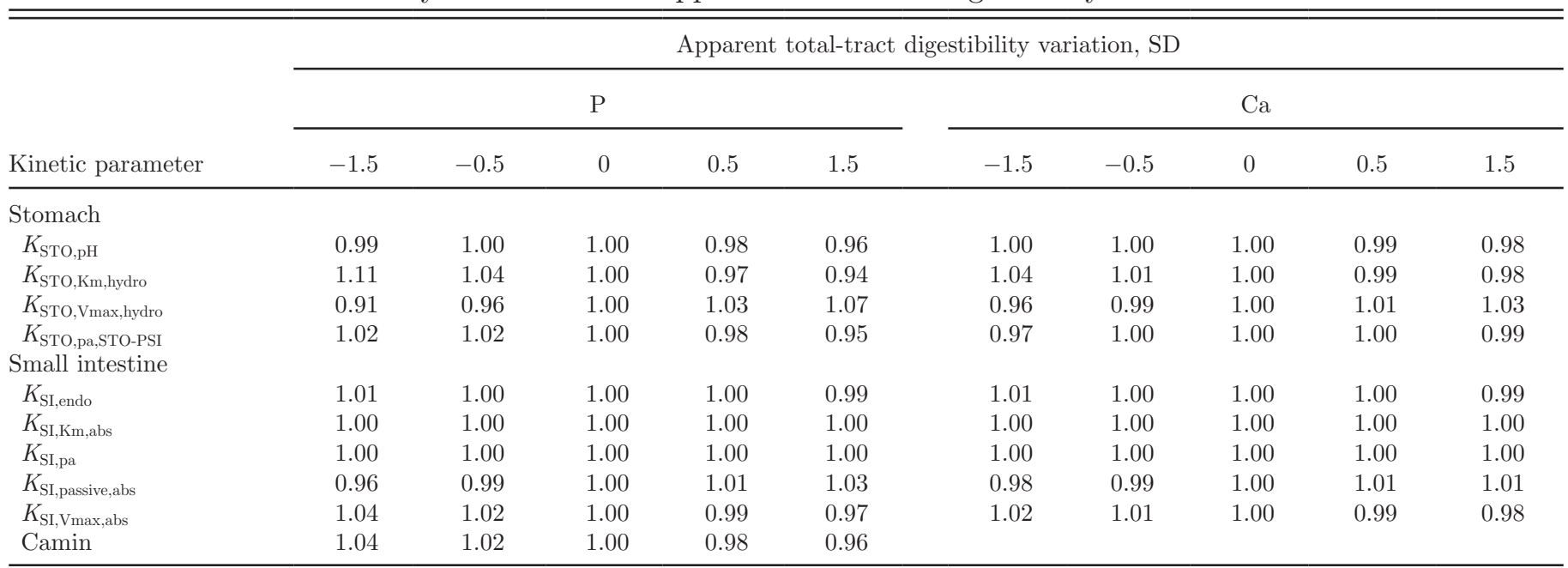

${ }^{1} K_{\mathrm{STO}, \mathrm{pH}}=\mathrm{pH}$ in the stomach; $K_{\mathrm{STO}, \text { Km,hydro }}=$ affinity constant of phytase; $K_{\mathrm{STO}, \text { Vmax.hydro }}=$ maximum velocity constant of phytase; $K_{\mathrm{STO}, \mathrm{pa}, \mathrm{STO}-\mathrm{PSI}}=$ rate of transit in the stomach; $K_{\mathrm{SI} \text {,endo }}=$ endogenous secretion in the small intestine; $K_{\mathrm{SI}, \mathrm{Km} \text {,abs }}=$ affinity constant of absorption in the small intestine; $K_{\mathrm{SI}, \mathrm{pa}}=$ rate of passage in the small intestine; $K_{\mathrm{SI} \text {,passive,abs }}=$ coefficient of passive absorption; $K_{\mathrm{SI}, \mathrm{Vmax} \text {,abs }}=$ maximum velocity constant of absorption; and Camin $=\mathrm{Ca}$ of mineral origin 


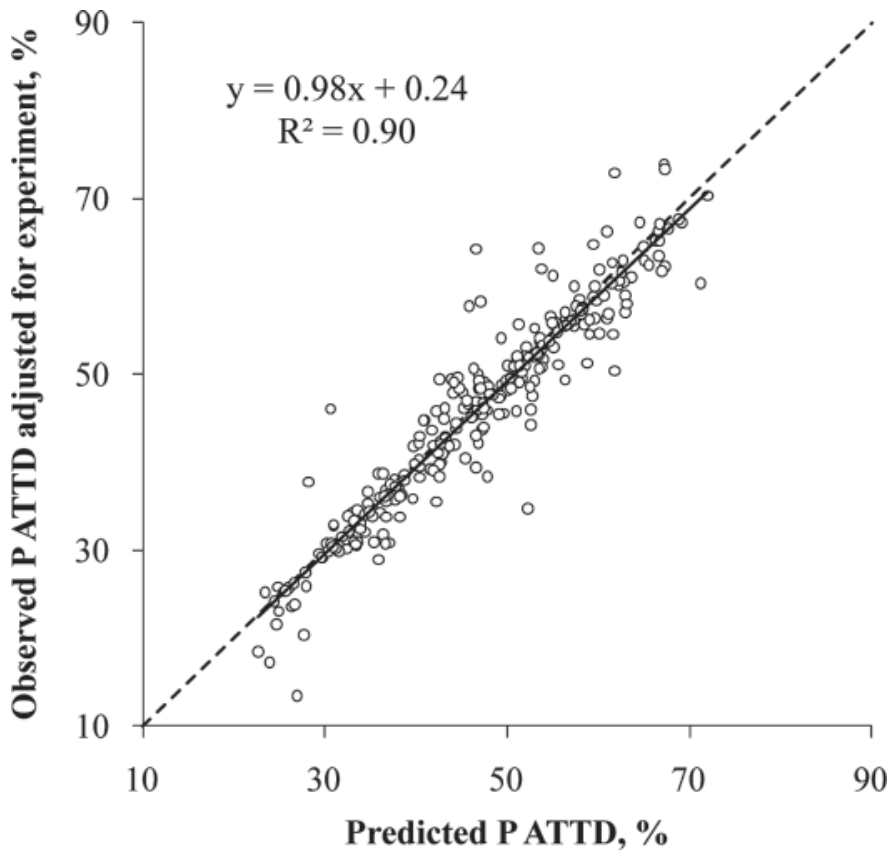

Figure 2. The relationship between observed apparent total-tract digestibility (ATTD) of P adjusted for experiment effect and predicted $\mathrm{P}$ ATTD. The number of observations $=281 ;$ No. of experiments $=66$; mean predicted P ATTD $=46.7 \%$; mean observed P ATTD $=46.0 \%$; mean square prediction error $=14.5$; error in central tendency $=0.46$; error due to regression $=0.05$; and error due to disturbance $=14.0$. Regression line $(-)$ and $\mathrm{Y}=\mathrm{X}$ line $(--)$.

on $K_{\mathrm{STO}, \mathrm{Km}, \text { hydro }}$; Table 3$)$. However, phytase hydrolysis parameters $\left(K_{\mathrm{STO}, \text { Vmax,hydro }}\right.$ and $\left.K_{\mathrm{STO}, \mathrm{Km} \text {,hydro }}\right)$ remained the most influential parameters of $\mathrm{P}$ and Ca ATTD in a supplemental phytase diet. The magnitude of the effect of varying phytase parameters was 2 times less for Ca than for $\mathrm{P}$, revealing a decreased effect of phytase on Ca ATTD than on P ATTD. To a lesser extent, $\mathrm{P}$ and $\mathrm{Ca}$ digestibility were also sensitive to the passive absorption coefficient $\left(K_{\mathrm{SI}, \text { passive,abs }}\right)$ and $\mathrm{V}_{\max }$ $\left(K_{\mathrm{STO}, \text { Vmax,abs }} ;<5 \%\right)$. The sensitivities of the small intestine transit rate $\left(K_{\mathrm{SI}, \mathrm{pa}}\right)$, endogenous inputs $\left(K_{\mathrm{SI} \text {,endo }}\right)$ of $\mathrm{P}$ and $\mathrm{Ca}$, and $K_{\mathrm{m}}$ of active absorption $\left(K_{\mathrm{SI}, \mathrm{Km}, \mathrm{abs}}\right)$ were nil. Finally, increasing dietary Ca concentrations decreased P ATTD linearly.

\section{Comparison of Simulated and Observed Digestibility Data}

The P ATTD can be predicted with adequate accuracy; the intercept and slope did not deviate from zero and one, respectively (Figure 2). There were also reduced percentages of the MSPE associated with the ECT (3.1\%) and ER (0.34\%), indicating that the average predicted and observed values are close and that the model predictions are unbiased $(\mathrm{Y}=\mathrm{X})$. The major portion of the MSPE (96.5\%) was associated with the ED, which represents the prediction error that has been accounted for by the model. However, the relative MSPE remained fairly low (8.3\%), indicating that the model seems to account for a large part of the observed variation. The prediction error for Ca ATTD was greater (10.1\%) than that for P ATTD and showed a larger bias (Figure 3). In fact, although the intercept and slope did not differ from zero and unity, respectively, the ECT, which was the difference between the predicted and observed values, accounted for the major part of the MSPE (71.3\%) and indicated that there is a systematic error in the prediction of Ca ATTD.

\section{General Model Behavior}

Kinetics of $\boldsymbol{P}$ and $\boldsymbol{C a}$ Absorption. The results of simulating $\mathrm{P}$ absorption from a corn- and soybean meal-based diet supplemented with microbial phytase or with monocalcium phosphate, both supplying the same amount of total absorbed $\mathrm{P}(\mathrm{g})$, indicated that $\mathrm{P}$ from the monocalcium phosphate-supplemented diet was absorbed more rapidly than $\mathrm{P}$ from the microbial phytase-supplemented diet (Figure 4). This should be expected because a large part of $\mathrm{P}$ in monocalcium phosphate enters the PSI in soluble form, whereas phytate $\mathrm{P}$ needs to be hydrolyzed before it can be solubilized and absorbed.

Effect of Phytase on $P$ and Ca Digestive Utilization. Considering the crucial role that this enzyme, phytase, plays regarding the utilization of $\mathrm{PP}$ by pigs, the effect of phytase on $\mathrm{P}$ and Ca utilization was tested. For that purpose, a P-deficient phytasefree diet was used as a control diet and compared with similar diets to which different amounts of phytM and phytPl had been added. The model predicted that

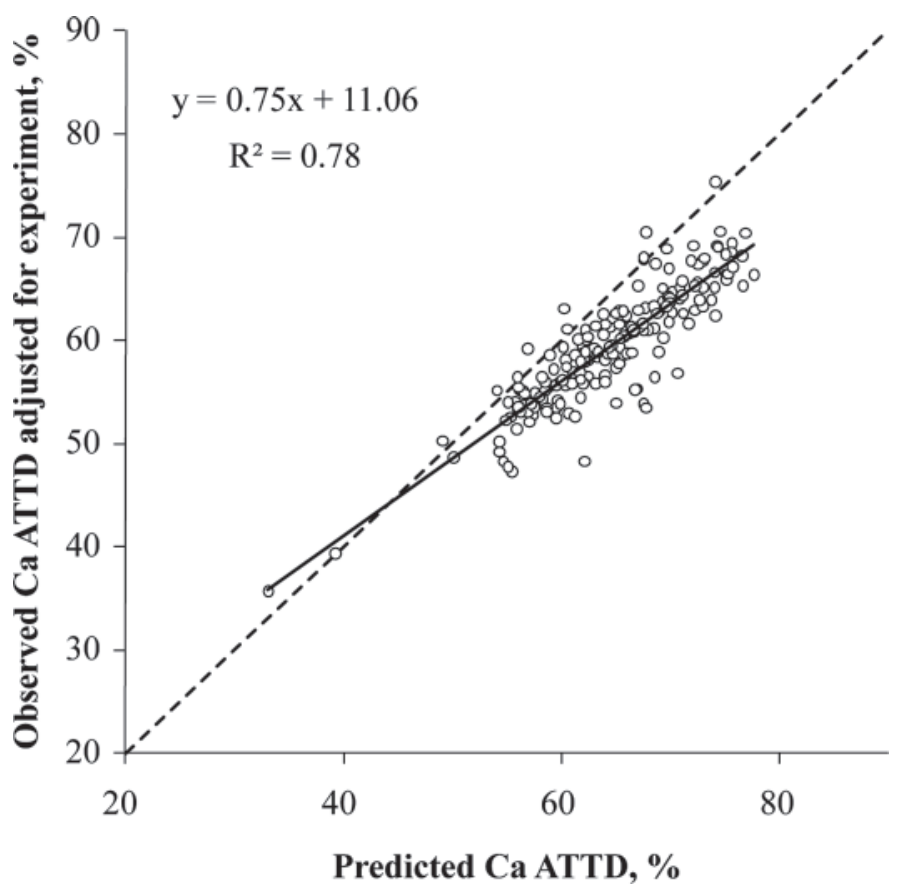

Figure 3. The relationship between observed apparent total-tract digestibility (ATTD) of Ca adjusted for experiment effect and predicted Ca ATTD. The number of observations $=193$; No. of experiments $=47$; mean predicted Ca ATTD $=64.3 \%$; mean observed Ca ATTD $=$ $59.3 \%$; mean square prediction error $=35.9$; error in central tendency $=25.6$; error due to regression $=2.97$; and error due to disturbance $=$ 7.32. Regression line $(-)$ and $\mathrm{Y}=\mathrm{X}$ line $(--)$. 

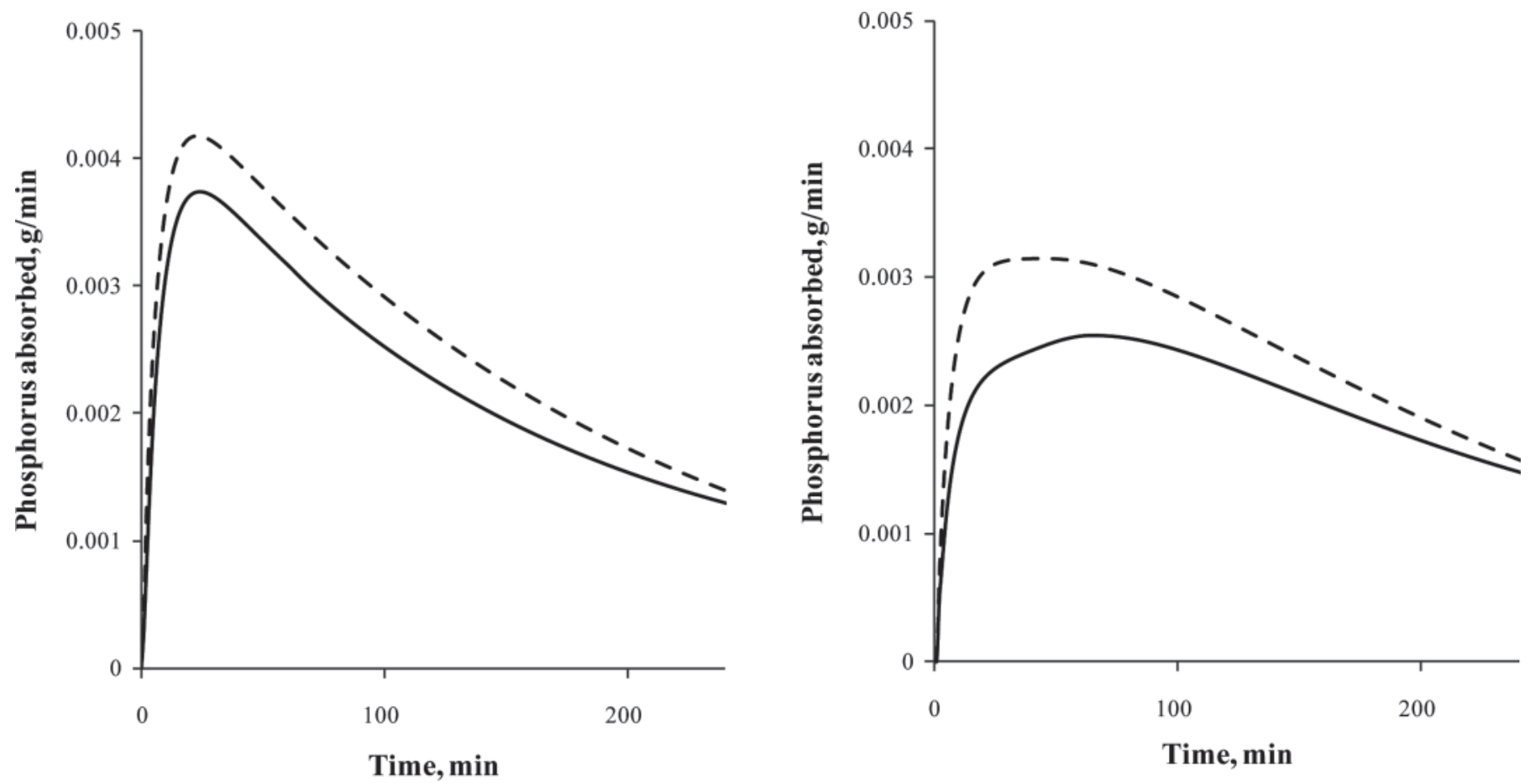

Figure 4. The pattern of $\mathrm{P}$ absorption in the proximal (-) and the distal (- - ) part of the small intestine of pigs after the ingestion of corn and soybean meal diets supplemented with (left) monocalcium phosphate or (right) microbial phytase, both supplying the same amount of total absorbed P.

the addition of 500 and 1,000 phytase units (FTU) of phytM per kilogram was equivalent to the addition of 0.82 and $1.17 \mathrm{~g}$ of digestible $\mathrm{P}$, respectively, compared with a diet without phytase. The addition of phytPl at $500 \mathrm{FTU} / \mathrm{kg}$ was equivalent to the addition of $0.50 \mathrm{~g}$ of digestible $\mathrm{P}$ with PP hydrolysis, about twice as low as the amount of digestible $\mathrm{P}$ obtained in the presence of phytM. Similarly, the effect of phytase on Ca digestibility predicted by the model was 0.53 and $0.76 \mathrm{~g}$ of digestible $\mathrm{Ca}$ for the addition of phytM at 500 and 1,000 FTU/kg, respectively.

Enzyme and Substrate Interaction. The amount of dietary PP can theoretically affect the amount of $\mathrm{P}$ liberated by this enzyme. The model showed that increasing the provision of dietary PP from 2.0 to 3.0 by $0.1-\mathrm{g} / \mathrm{kg}$ increments increased the digestible $\mathrm{P}$ liberated by phytM $(400 \mathrm{FTU} / \mathrm{kg})$ by $0.06 \mathrm{~g}$. For a fixed dietary $\mathrm{PP}$ concentration of $2.3 \mathrm{~g} / \mathrm{kg}$, increasing the phytase supply from 0 to $2,000 \mathrm{FTU} / \mathrm{kg}$ by $400-\mathrm{FTU} / \mathrm{kg}$ increments increased the liberated digestible $\mathrm{P}$ by $0.71,1.06$, $1.25,1.37$, and $1.44 \mathrm{~g} / \mathrm{kg}$ compared with a diet without phytase. The amount of digestible $\mathrm{P}$ liberated became marginal at greater quantities of phytase supply. The model also revealed that for a given phytase supply, increasing PP supply increased the amount of P liberated by phytase (interaction between the amount of $\mathrm{PP}$ and that of phytM).

Effect of Dietary Ca on $\boldsymbol{P}$ Utilization. Greater dietary $\mathrm{Ca}$ concentration is known to reduce $\mathrm{P}$ digestive utilization in pigs. The model showed that increasing dietary Ca from 6 to $10 \mathrm{~g}$ by 1 -g increments decreased digestible $\mathrm{P}$ by $2 \%$, regardless of the dietary concentra- tion of $\mathrm{Ca}$ and $\mathrm{P}$, owing to the formation of insoluble complexes between NPPs and Cas in the DSI compartment. Unfortunately, literature data evaluating the effect of dietary $\mathrm{Ca}$ concentration on $\mathrm{P}$ digestive utilization are scarce, and the few data available were already used to parameterize the model mechanisms regulating the formation of $\mathrm{P}$ and $\mathrm{Ca}$ complexes. Therefore, model results in this area did not allow proper evaluation of this effect.

Effect of Feed Formulation Imprecision on Digestible $\boldsymbol{P}$ and $\boldsymbol{C a}$. Model results revealed that there are no model parameters with extreme influence on P and Ca ATTD. Digestible P and Ca were therefore determined by their dietary concentration and chemical form as well as by the presence of phytases in the feed. Several situations of variation in nutrient composition resulting from imprecision in the feed formulation and manufacturing process have therefore been tested to quantify their effect on the final amount of digestible $\mathrm{P}$ available to pigs. Underestimation of the amount of dietary Ca supply was tested first to simulate practical situations resulting from an underestimation of the amount of $\mathrm{CaCO}_{3}$, the most common mineral source for $\mathrm{Ca}$, incorporated into feeds. Increasing dietary Ca supply in diets by $20 \%$ reduced P ATTD by only $3 \%$. According to the proposed model, the reported variation in apparent digestibility of dicalcium phosphate $\mathrm{P}$ represented a 9\% difference in P ATTD compared with the default value. Furthermore, as observed in the database compiled for model evaluation, large differences can be seen between the expected and measured phytase activity of feeds; $95 \%$ of the population was between 0.6 and 
1.4 of phytase activity expected/measured. Simulating these differences in phytase activity in a standard commercial diet supplemented with $500 \mathrm{FTU} / \mathrm{kg}$ led to variations of $14 \%$ in total P ATTD.

\section{DISCUSSION}

\section{Sensitivity Analysis}

Although the sensitivity of model responses to individual changes of model parameters in terms of $\mathrm{P}$ and Ca ATTD was generally low, the effect of some parameters should be discussed. The parameters characterizing phytase activity showed the greatest sensitivity. Because of the availability of data, $V_{\max }$ constant values were taken from in vitro studies, whereas the $K_{\mathrm{m}}$ were adjusted to represent in vivo observations. In fact, in vitro data were used when in vivo data were not available. Moreover, the use of in vivo rather than in vitro data would probably provide $K_{\mathrm{m}}$ values closer to in vivo digestive conditions (Gill et al., 1989). Parameters characterizing hydrolysis flows are different among commercial phytases. Therefore, given the high sensitivity of phytate $\mathrm{P}$ hydrolysis ( -13 to $52 \%$ ) and, to a lesser extent, the sensitivity of P ATTD ( -9 to $+11 \%)$ to changes in these parameters, phytases other than the ones from plants and $A$. niger can also be simulated by the model. The second most sensitive parameter in terms of P ATTD was the dietary concentration of Ca $( \pm 4 \%)$ followed by STO $\mathrm{pH}(-4$ to $0 \%)$. The negative effect of increasing STO pH on $\mathrm{P}$ ATTD can result from PP solubility, which was dramatically low at high $\mathrm{pH}(>6)$ because of the formation of insoluble complexes with divalent cations (Cheryan, 1980; Pontoppidan et al., 2007).

The sensitivity analysis also showed that the parameters that were more difficult to estimate from the literature have little or no effect on model responses. The rate of the passage of digesta through the different digestive compartments is difficult to measure in vivo, but the ATTD of $\mathrm{P}$ and $\mathrm{Ca}$ has decreased sensitivity to these parameters in the STO $(-5$ to $+2 \%)$ and was insensitive in the small intestine. Using an average MRT value was therefore adequate, although large variations were observed in the literature (Low, 1990). The limited representation of transit of digesta should not have consequences on the capability of the model to represent the digestive fate of dietary $\mathrm{Ca}$ and $\mathrm{P}$. This was also the case for $\mathrm{P}$ and $\mathrm{Ca}$ absorption parameters. Although the knowledge regarding the amount of $\mathrm{P}$ and $\mathrm{Ca}$ that is absorbed in the different sections of the small intestine is limited and the estimation of the absorption parameters is difficult, the representation of this phenomenon had a reduced effect on ATTD. However, the homeostasis of $\mathrm{Ca}$ in blood and extracellular fluids represents one of the finest biological control systems in animals and is achieved by a variety of hormones that regulate the transcellular $\mathrm{Ca}$ and $\mathrm{P}$ absorption processes (Civitelli and Avioli, 1994). Therefore, a reduced sensitivity of the model to extreme dietary concentrations of $\mathrm{P}$ and Ca can be expected when it will be linked to a model representing the metabolic fate of these minerals.

\section{Prediction of $P$ and Ca Digestibility}

Mineral digestibility reflects digestion processes (e.g., solubilization, insolubilization, transit, and hydrolysis) and absorption from the gastrointestinal lumen. Digestion and absorption involve nutrients that originate from the diet or from endogenous secretions into the digestive tract of the animal. Because $\mathrm{P}$ and $\mathrm{Ca}$ are absorbed mainly from the SI, it is considered that the microbial activity in the large intestine does not modify the amount of $\mathrm{P}$ and Ca absorbed (Jongbloed, 1987). However, it should be noted that Fan and Sauer (2002) concluded that the role of the large intestine in wholebody $\mathrm{P}$ homeostasis needs to be clarified before using apparent $\mathrm{P}$ digestibility values in diet formulation.

Comparing model outcomes with independent literature data showed that P ATTD was adequately predicted and unbiased. The current model consistently predicted $\mathrm{P}$ ATTD, taking into account the form of $\mathrm{P}$ supply, dietary Ca concentration, and phytase supplementation. However, the same was not true for $\mathrm{Ca}$ ATTD; the prediction error was relatively high (root MSPE $=10.1 \%$ ) and the predictions tended to be biased $(\mathrm{ECT}=71.3 \%$; $\mathrm{ER}=8.3 \%$; and $\mathrm{ED}=20.4 \%) . \mathrm{A}$ careful study of the differences between predicted and observed Ca ATTD indicated that the model-predicted digestibility overestimation was generally associated with particular feedstuffs and publications. Prediction of Ca ATTD from corn and soybean meal diets was better $($ root $\mathrm{MSPE}=4.9 \% ; \mathrm{ECT}=19.5 \%$; $\mathrm{ER}=2.2 \%$; and $\mathrm{ED}=78.3 \%$ ). The characteristics of some ingredients that are not present or present at decreased proportions in corn and soybean meal diets (e.g., dietary fiber and Ca oxalate salts) have a substantial effect on Ca ATTD and are not taken into account by the model (Civitelli and Avioli, 1994). Furthermore, considerable differences between predicted and published Ca ATTD were observed for experiments carried out by specific authors (e.g., Jongbloed and Kemme, 1990; Kemme et al., 1997). In those experiments, the model showed a systematic overestimation of Ca ATTD regardless of diet composition. It should be noted, however, that most of the diets used in those experiments did not include corn or soybean meal as principle ingredients. It is possible that the systematic overestimation of predicted Ca ATTD was due to differences in analytical methods. In fact, nitric acid, rather than the stronger acids such as perchloric acid, which is commonly used in North America, had been used in those studies. Further research is needed to determine whether the model overestimates the amount of absorbed $\mathrm{Ca}$ by failing to take into account the effect of some dietary components on Ca ATTD or by including the analytical method as an independent variable. 


\section{Prediction of the Effect of Phytase on $P$ and Ca Utilization}

The amount of digestible $\mathrm{P}$ and $\mathrm{Ca}$ delivered by phytM was in agreement with previous literature values (i.e., $0.8 \mathrm{~g}$ of digestible P for $500 \mathrm{FTU} / \mathrm{kg}$; Kornegay, 2001; Selle and Ravindran, 2008). Moreover, the hydrolysis of $\mathrm{P}$ by phytM was 1.4 to 2.5 times greater than hydrolysis by phytPl (Weremko et al., 1997; Zimmermann et al., 2003; Létourneau-Montminy et al., 2010). The model was able to accurately simulate the effect of $A$. niger phytM, as well as the effect of phytPl on the digestive utilization of $\mathrm{P}$ and $\mathrm{Ca}$.

Notable inconsistencies of the effect of phytase on the digestive utilization of $\mathrm{P}$ and $\mathrm{Ca}$ are reported in the literature. These inconsistencies can be associated with variations in 1) the origin and concentration of the $\mathrm{PP}$, 2 ) the origin of the phytase, 3) the real phytase activity, and 4) the dietary $\mathrm{Ca}$ and $\mathrm{P}$ concentrations of the reference diet (Selle and Ravindran, 2008). The model did indeed show an effect of the first 3 listed sources of variation. A positive relationship between substrate concentration and the magnitude of the response to dietary phytase supplementation was depicted by the model, in agreement with the findings of Fandrejewski et al. (1999) and Sands et al. (2009). This observation and the model results corroborate the statement by Selle and Ravindran (2008) that the interaction between phytate and phytase has to be considered when giving dietary recommendations and optimizing the efficiency with which phytase releases $\mathrm{P}$ from phytate. Further studies are needed to accurately estimate the amount of PP that phytase can release. In accordance with previous research, the effect of the origin of the phytate on the $\mathrm{P}$ released by phytase also needs to be clarified (Rapp et al., 2001), and if found to be important, it should be included in the model. This enzyme-substrate interaction also emphasizes the need to standardize the conditions under which phytases are evaluated to ensure their adequate use in diet formulation (Powers and Angel, 2008; Selle and Ravindran, 2008).

\section{Prediction of the Effect of Dietary Ca Concentration on P Digestibility}

Dietary $\mathrm{Ca}$ is well known to modify $\mathrm{P}$ utilization; the interaction between these 2 essential minerals occurs at the digestive and metabolic levels (Jongbloed et al., 1999). The simulated negative effect of dietary $\mathrm{Ca}$ on the utilization of $\mathrm{P}$ has to be evaluated in vivo, given that all data available from the literature were used for model development and parameterization. At least 3 mechanisms have been proposed to explain the detrimental effect of increased concentrations of dietary $\mathrm{Ca}$ on $\mathrm{P}$ utilization: 1) excess dietary $\mathrm{Ca}$ tends to form insoluble complexes with phytate, rendering them unavailable for hydrolysis in the STO (Wise, 1983) and small intestine (Cromwell, 1996); 2) high dietary
$\mathrm{Ca}$ favors an increase in digestive tract $\mathrm{pH}$, which in turn decreases phytM activity and phytate solubility (Sandberg et al., 1993; Selle and Ravindran, 2008); and 3 ) excess $\mathrm{Ca}$ can form insoluble complexes with phosphate in the small intestine (Cromwell, 1996). Only the latter mechanism is represented in the proposed model. The formation of insoluble phytate-Ca complexes in the STO has been demonstrated in vitro (Selle et al., 2009). In the few available in vivo studies assessing the effect of dietary Ca concentration on phytase efficiency using both supplemented and unsupplemented diets, the negative effect of dietary $\mathrm{Ca}$ on $\mathrm{P}$ utilization seemed to be independent of phytase (Adeola et al., 2006; Létourneau-Montminy et al., 2010; Narcy et al., 2010). The interaction between $\mathrm{Ca}$ and phytases was not represented in the model because of the lack of consensus and literature data regarding this phenomenon. Furthermore, the available information on the reduction of digestive $\mathrm{pH}$ by the addition of $\mathrm{Ca}$ is limited, and this factor has not yet been represented in the proposed model.

\section{Model Components}

The proposed model allows estimation of the proportions of dietary $\mathrm{P}$ and, to a lesser extent, dietary $\mathrm{Ca}$ that are absorbed, taking into consideration the chemical dietary forms and the presence of phytase. Although the efficiency of $\mathrm{P}$ and $\mathrm{Ca}$ absorption is known to be also regulated by the requirement for these nutrients (Partridge, 1980; Rodehutscord et al., 1999), which also depends on the mineral status of the animal (Fammatre et al., 1977; Létourneau-Montminy et al., 2010), and by BW (Kemme et al., 1997), the model was built to simulate only digestive phenomenon controlling the fate of dietary P. Also, the absence of metabolic factors may limit the accurate representation of the endogenous secretions and, thus, the requirements of the pig (Partridge, 1980). Indeed, fecal endogenous losses may be greater in pigs fed $\mathrm{P}$ - and Ca-sufficient diets compared with insufficient ones (Guéguen and Perez, 1981; Jongbloed and Everts, 1992). The extension of this model to account for endogenous $\mathrm{Ca}$ and $\mathrm{P}$ flows, as well as nutrient interactions and absorption regulation, will be considered in future model development.

Another important aspect of the model is the representation of the $\mathrm{pH}$ in the gastrointestinal tract. To the knowledge of the authors, this model is the first digestion model to dynamically represent gastric $\mathrm{pH}$. For simplicity, $\mathrm{pH}$ is represented dynamically only in the STO compartment of the model, given that gastric $\mathrm{pH}$ homeostasis has been widely studied and information on $\mathrm{P}$ and $\mathrm{Ca}$ solubilization and insolubilization and hydrolysis because of $\mathrm{pH}$ is well documented. However, $\mathrm{pH}$ representation in the STO is currently limited because it does not include the effects of the nature and quantity of food or pig BW, which can all modify gastric secretions and, thus, $\mathrm{pH}$ (Kidder and Manners, 1978). Nevertheless, the chosen mechanistic representa- 
tion will allow evaluation of the relevance of introducing these factors into the model and the quantitative effect on $\mathrm{P}$ and Ca utilization.

\section{Optimization of the Efficacy of Phytase in Releasing $P$ and $\mathrm{Ca}$}

According to the proposed model, phytM at $1,000 \mathrm{FTU} / \mathrm{kg}$ can degrade approximately $60 \%$ of the phytate present in common corn and soybean meal diets. That amount is the maximum phytase supplementation used in practice. The proposed model can provide alternatives to improve phytase efficiency and optimize the utilization of plant $\mathrm{P}$. The model revealed that phytase efficacy can be improved by increasing the amount of PP that enters into solution in the STO. This finding is consistent with the assumption that phytate solubility is a limiting factor for gastric phytate degradation, as observed in in vivo studies (Kemme, 1998; Schlemmer et al., 2001; Kemme et al., 2006). Three parameters in the proposed model make it possible to increase the solubility of PP. Without phytase, PPns is solubilized to PPs depending on $\mathrm{pH}$, as suggested in the in vitro study by Pontoppidan et al. (2007). Those authors showed a decline in PP solubility before and, with a greater magnitude, after the optimal $\mathrm{pH}$ value of 4.4 (at which phytate solubility attains its maximum value of $60 \%$ ) was reached. The model simulates an immediate increase in STO pH to 5 after the meal and then a progressive decrease until pH 3 is reached $12 \mathrm{~h}$ later (Chiang et al., 2008). Therefore, phytate hydrolysis can be improved by inducing a rapid decrease in STO pH to the optimal value of 4.4. This decrease can be achieved by means of organic acids or acidifying salts. It should be noted that the less than $60 \%$ maximum solubility of plant phytate at the $\mathrm{STO} \mathrm{pH}$ greatly compromises the improvement of its hydrolysis by phytase. Indeed, if we speculate that the overall PPns pool can entirely join the PPs pool, the model shows that PP can be hydrolyzed at $84 \%$ with the addition of $1,000 \mathrm{FTU} / \mathrm{kg}$. Further research is, thus, needed to highlight and quantify the factors that can improve phytate solubility, dietary levels of divalent cations (e.g., Ca, $\mathrm{Zn}$, and $\mathrm{Cu}$ ) and proteins (Cheryan, 1980), and the acid-binding capacity of feedstuffs (Lawlor et al., 2005). Additionally, based on sensitivity analysis, it is reasonable to think that increasing the lag time, during which PP is exposed to phytase, can improve plant $\mathrm{P}$ digestive utilization. Stomach MRT can be decreased by increasing, for instance, the fat or starch content in diets (Low, 1990).

Finally, extending the activity of phytase to the small intestine can be considered but would be challenging. Indeed, phytase effectiveness is compromised first by the higher $\mathrm{pH}$ observed in the small intestine compared with the STO because of a reduction in phytase activity (Eeckhout and De Paepe, 1992) and phytate solubility (Schlemmer et al., 2001) and second by the presence of protease (e.g., pancreatin; Phillippy, 1999).
The proposed model integrates the most relevant physiological processes involved in $\mathrm{P}$ digestion and absorption, including $\mathrm{P}$ dietary forms, the presence of exogenous phytase, and the dietary concentration of $\mathrm{Ca}$. It can be used as a prospective tool to study $\mathrm{P}$ digestibility for different feedstuffs and feeding strategies, as well as the effect of specific digestive processes on $\mathrm{P}$ digestive utilization. Nevertheless, further model refinements are needed to include the metabolic flows of $\mathrm{P}$ and $\mathrm{Ca}$ and to account for the metabolic regulation of $\mathrm{Ca}$ and $\mathrm{P}$ absorption.

\section{LITERATURE CITED}

Adeola, O., O. A. Olukosi, J. A. Jendza, R. N. Dilger, and M. R. Bedford. 2006. Response of growing pigs to Peniophora lyciiand Escherichia coli-derived phytases or varying ratios of calcium to total phosphorus. Anim. Sci. 82:637-644.

Bastianelli, D., D. Sauvant, and A. Rerat. 1996. Mathematical modeling of digestion and nutrient absorption in pigs. J. Anim. Sci. 74:1873-1887.

Besançon, P., and L. Guéguen. 1969. Les principales voies du métabolisme calcique chez le porc en croissance. Ann. Biol. Anim. Biochim. Biophys. 9:537-553.

Bibby, J., and H. Toutenburg. 1977. Prediction and Improved Estimation in Linear Models. J. Wiley and Sons, New York, NY.

Braude, R., R. J. Fulford, and A. G. Low. 1976. Studies on digestion and absorption in the intestines of growing pigs. Measurements of the flow of digesta and pH. Br. J. Nutr. 36:497-510.

Cheryan, M. 1980. Phytic acid interactions in food systems. Crit. Rev. Food Sci. Nutr. 13:297-335.

Chiang, C. C., J. Croom, S. T. Chuang, P. W. S. Chiou, and B. Yu. 2008. Development of a dynamic system simulating pig gastric digestion. Asian-australas. J. Anim. Sci. 21:1522-1528.

Civitelli, R., and L. V. Avioli. 1994. Calcium, phosphate, and magnesium absorption. Pages 2173-2181 in Physiology of the Gastrointestinal Tract. 3rd ed. L. R. Johnson, ed. Raven Press, New York, NY.

Code, C. F., and J. A. Marlett. 1975. The interdigestive myo-electric complex of the stomach and small bowel of dogs. J. Physiol. 246:289-309.

Correll, D. L. 1999. Phosphorus: A rate limiting nutrient in surface waters. Poult. Sci. 78:674-682.

Cromwell, G. L. 1996. Metabolism and role of phosphorus, calcium, and vitamin $\mathrm{D}_{3}$ in swine nutrition. Pages 101-110 in Phytase in Animal Nutrition and Waste Management. M. B. Coelho and E. T. Kornegay, ed. BASF Corporation, Mount Olive, NJ.

Cuber, J. C., C. Kabore, and J. P. Laplace. 1981. Évacuation gastrique comparée de l'orge et du blé broyés chez le porc. Reprod. Nutr. Dev. 21:773. (Abstr.)

Cuber, J. C., and J. P. Laplace. 1979. Évacuation gastrique de la matière sèche d'un régime semi-purifié à base d'amidon de maïs chez le porc. Ann. Biol. Anim. Biochim. Biophys. 19:899-905.

Darcy, B., J. P. Laplace, and P. A. Villiers. 1980. Digestion dans l'intestin grêle chez le porc. 2.-Cinétique comparée de passage des digesta selon le mode de fistulation, iléocaecale ou iléocolique post-valvulaire, dans diverses conditions d'alimentation. Ann. Zootech. 29:147-177.

Eeckhout, W., and M. De Paepe. 1992. Phytase de blé, phytase microbienne et digestibilité apparente du phosphore d'un aliment simple pour porcelets. Rev. Agric. 45:195-207.

Fammatre, C. A., D. C. Mahan, A. W. Fetter, A. P. Grifo Jr., and J. K. Judy. 1977. Effects of dietary protein, calcium and phosphorus levels for growing and finishing swine. J. Anim. Sci. 44:65-71.

Fan, M. Z., and W. C. Sauer. 2002. Additivity of apparent ileal and fecal phosphorus digestibility values measured in single 
feed ingredients for growing-finishing pigs. Can. J. Anim. Sci. 82:183-191.

Fandrejewski, H., D. Weremko, S. Raj, G. Skiba, and I. K. Han. 1999. Performance, body and carcass composition and bone characteristics of pigs fed rapeseed and soyabean meal-cereal diets supplemented with microbial phytase. J. Anim. Feed Sci. 8:533-547.

Fernández, J. A. 1995a. Calcium and phosphorus metabolism in growing pigs. II. Simultaneous radio-calcium and radio-phosphorus kinetics. Livest. Prod. Sci. 41:243-254.

Fernández, J. A. 1995b. Calcium and phosphorus metabolism in growing pigs. III. A model resolution. Livest. Prod. Sci. $41: 255-261$

Fox, J., A. D. Care, and R. Swaminathan. 1978. The use of a ThiryVella loop of jejunum to study the intestinal absorption of calcium and inorganic phosphate in the conscious pig. Br. J. Nutr. 39:431-439.

Fox, J., R. Swaminathan, T. M. Murray, and A. D. Care. 1977. Role of the parathyroid glands in the enhancement of intestinal calcium absorption in response to a low calcium diet. J. Endocrinol. 74:345-354.

Gill, M., D. E. Beever, and J. France. 1989. Biochemical bases needed for the mathematical representation of whole animal metabolism. Nutr. Res. Rev. 2:181-200.

Graf, E. 1983. Calcium binding to phytic acid. J. Agric. Food Chem. 31:851-855.

Gregory, P. C., M. McFadyen, and D. V. Rayner. 1990. Pattern of gastric emptying in the pig: Relation to feeding. Br. J. Nutr. 64:45-58.

Guéguen, L., and J. M. Perez. 1981. A re-evaluation of recommended dietary allowances of calcium and phosphorus for pigs. Proc. Nutr. Soc. 40:273-278.

Heaney, R. P., and B. E. C. Nordin. 2002. Calcium effects on phosphorus absorption: Implications for the prevention and co-therapy of osteoporosis. J. Am. Coll. Nutr. 21:239-244.

Jongbloed, A. W. 1987. Phosphorus in the feeding of pigs: Effect of diet on the absorption and retention of phosphorus by growing pigs. PhD Diss. Institut voor Veevoedingsonderzoek, Lelystad, the Netherlands.

Jongbloed, A. W., and H. Everts. 1992. Apparent digestible phosphorus in the feeding of pigs in relation to availability, requirement and environment. 2. The requirement of digestible phosphorus for piglets, growing-finishing pigs and breeding sows. Neth. J. Agric. Sci. 40:123-136.

Jongbloed, A. W., H. Everts, P. A. Kemme, and Z. Mroz. 1999. Quantification of absorbability and requirements of macroelements. Pages 275-298 in A Quantitative Biology of the Pig. I. Kyriazakis, ed. CAB International, Wallingford, UK.

Jongbloed, A. W., and P. A. Kemme. 1990. Effect of pelleting mixed feeds on phytase activity and the apparent absorbability of phosphorus and calcium in pigs. Anim. Feed Sci. Technol. 28:233-242.

Jongbloed, A. W., P. A. Kemme, G. De Groote, M. Lippens, and F. Meschy. 2002. Bioavailability of Major and Trace Minerals. International Association of the European Manufacturers of Major, Trace and Specific Feed Mineral Materials (EMFEMA), Brussels, Belgium.

Jongbloed, A. W., Z. Mroz, and P. A. Kemme. 1992. The effect of supplementary Aspergillus niger phytase in diets for pigs on concentration and apparent digestibility of dry matter, total phosphorus, and phytic acid in different sections of the alimentary tract. J. Anim. Sci. 70:1159-1168.

Kemme, P. A. 1998. Phytate and phytases in pig nutrition: Impact on nutrient digestibility and factors affecting phytase efficacy. PhD Diss. Utrecht Univ., Utrecht, the Netherlands.

Kemme, P. A., A. W. Jongbloed, Z. Mroz, and A. C. Beynen. 1997. The efficacy of Aspergillus niger phytase in rendering phytate phosphorus available for absorption in pigs is influenced by pig physiological status. J. Anim. Sci. 75:2129-2138.
Kemme, P. A., U. Schlemmer, Z. Mroz, and A. W. Jongbloed. 2006. Monitoring the stepwise phytate degradation in the upper gastrointestinal tract of pigs. J. Sci. Food Agric. 86:612-622.

Kidder, D. E., and M. J. Manners. 1978. Digestion in the Pig. Kingston Press, Bath, UK.

Kim, T., E. J. Mullaney, J. M. Porres, K. R. Roneker, S. Crowe, S. Rice, T. Ko, A. H. J. Ullah, C. B. Daly, R. Welch, and X. G. Lei. 2006. Shifting the $\mathrm{pH}$ profile of Aspergillus niger PhyA phytase to match the stomach $\mathrm{pH}$ enhances its effectiveness as an animal feed additive. Appl. Environ. Microbiol. 72:4397-4403.

Kornegay, E. T. 2001. Digestion of phosphorus and other nutrients: The role of phytases and factors influencing their activity. Pages 237-271 in Enzymes in Farm Animal Nutrition. M. R. Bedford and G. G. Partridge, ed. CAB International, Wallingford, UK.

Kornegay, E. T., J. S. Radcliffe, and D. M. Denbow. 1996. Influence of natuphos phytase on calcium bioavailability in plant ingredients and development of calcium equivalency values for swine and poultry. Pages 419-434 in Phytase in Animal Nutrition and Waste Management. M. B. Coehlo and E. T. Kornegay, ed. BASF Corporation, Mount Olive, NJ.

Lantzsch, H. J., S. Wjst, and W. Drochner. 1995. The effect of dietary calcium on the efficacy of microbial phytase in rations for growing pigs. J. Anim. Physiol. Anim. Nutr. (Berl.) 73:19-26.

Laplace, J. P. 1970. Mensurations, in vivo et post mortem, et croissance de l'intestin grêle chez le porc. Ann. Zootech. 19:465469.

Laplace, J. P., A. Aumaitre, and A. Rerat. 2001. Forty years of achievement in French research on digestive physiology in the pig. Reprod. Nutr. Dev. 41:129-151.

Laplace, J. P., O. Pons, J. C. Cuber, C. Kabore, and P. A. Villiers. 1981. Effets de la nature de l'amidon (blé ou maïs) et des protéines (poisson ou gluten) sur les facteurs de contrôle et le décours de l'évacuation gastrique d'un régime semi-purifié chez le porc. Applications de l'analyse multidimensionnelle et de la régression polynomiale. Ann. Zootech. 30:209-248.

Larsen, T., and B. Sandström. 1993. Effect of dietary calcium level on mineral and trace element utilization from a rapeseed (Brassica napus L.) diet fed to ileum-fistulated pigs. Br. J. Nutr. 69:211-224

Lawlor, P. G., P. B. Lynch, P. J. Caffrey, J. J. O'Reilly, and M. K. O'Connell. 2005. Measurements of the acid-binding capacity of ingredients used in pig diets. Ir. Vet. J. 58:447-452.

Létourneau-Montminy, M. P., and A. Narcy. 2010. Meta-analysis of phosphorus digestive and metabolic utilization by growing pigs: Effect of dietary phosphorus, calcium and exogenous phytase. Can. J. Anim. Sci. 90:595-605.

Létourneau-Montminy, M. P., A. Narcy, M. Magnin, D. Sauvant, J. F. Bernier, C. Pomar, and C. Jondreville. 2010. Effect of reduced dietary calcium concentration and phytase supplementation on calcium and phosphorus utilization in weaned piglets with modified mineral status. J. Anim. Sci. 88:1706-1717.

Liu, J., D. W. Bollinger, D. R. Ledoux, and T. L. Veum. 1998. Lowering the dietary calcium to total phosphorus ratio increases phosphorus utilization in low-phosphorus corn-soybean meal diets supplemented with microbial phytase for growing-finishing pigs. J. Anim. Sci. 76:808-813.

Low, A. G. 1990. Nutritional regulation of gastric secretion, digestion and emptying. Nutr. Res. Rev. 3:229-252.

Moore, J. H., and C. Tyler. 1955. Studies on the intestinal absorption and excretion of calcium and phosphorus in the pig. 1. A critical study of the Bergeim technique for investigating the intestinal absorption and excretion of calcium and phosphorus. Br. J. Nutr. 9:63-80.

Narcy, A., M. P. Létourneau-Montminy, E. Bouzouagh, N. Même, M. Magnin, and J. Y. Dourmad. 2010. Effect of dietary calcium concentration and microbial phytase addition on $\mathrm{P}$ utilization in weaned pigs. J. Anim. Sci. 88(Suppl. 2):1107 (Abstr.)

Noakes, D. E., P. D. Cranwell, and K. J. Hill. 1968. Studies on gastric secretion in the pig. Proc. Nutr. Soc. 27:2A-3A. 
Nuhoglu, A., and B. Yalcin. 2005. Modelling of phenol removal in a batch reactor. Process Biochem. 40:1233-1239.

Offner, A., and D. Sauvant. 2004. Comparative evaluation of the Molly, CNCPS, and LES rumen models. Anim. Feed Sci. Technol. 112:107-130.

Pansu, D., C. Bellaton, and C. Roche. 1984. Absorption intestinale du calcium et sa régulation. Phénomènes tissulaires, membranaires et moléculaires. Diabete Metab. 10:106-120.

Partridge, I. G. 1978. Studies on digestion and absorption in the intestines of growing pigs. 3. Net movements of mineral nutrients in the digestive tract. Br. J. Nutr. 39:527-537.

Partridge, I. G. 1980. Mineral nutrition of the pig. Proc. Nutr. Soc. 39:185-192

Perez, J. M., P. Mornet, and A. Rérat. 1986. Le Porc et Son Élevage. Bases Scientifiques et Techniques. Maloine, Paris, France.

Phillippy, B. Q. 1999. Susceptibility of wheat and Aspergillus niger phytases to inactivation by gastrointestinal enzymes. J. Agric. Food Chem. 47:1385-1388.

Pointillart, A. 1994. Phytates, phytases: Leur importance dans l'alimentation des monogastriques. INRA Prod. Anim. 7:2939.

Pomar, C., and M. Marcoux. 2005. The accuracy of measuring backfat and loin muscle thickness on pork carcasses by the Hennessy HGP2, Destron PG-100, CGM and ultrasound CVT grading probes. Can. J. Anim. Sci. 85:481-492.

Pommier, S. A., C. Pomar, C. Gariépy, and D. Petitclerc. 1993. Influence du génotype, de la castration, de la somatocrinine et d'une restriction énergétique sur la qualité des viandes et les propriétés de transformation des carcasses de porcs. Rapport final de l'entente auxiliaire Canada-Québec sur le développement agro-alimentaire. Quebec, Canada.

Pontoppidan, K., D. Pettersson, and A. S. Sandberg. 2007. Interaction of phytate with protein and minerals in a soybean-maize meal blend depends on $\mathrm{pH}$ and calcium addition. J. Sci. Food Agric. 87:1886-1892.

Powers, W., and R. Angel. 2008. A review of the capacity for nutritional strategies to address environmental challenges in poultry production. Poult. Sci. 87:1929-1938.

Qian, H., E. T. Kornegay, and D. E. Conner Jr. 1996. Adverse effects of wide calcium:phosphorus ratios on supplemental phytase efficacy for weanling pigs fed two dietary phosphorus levels. J. Anim. Sci. 74:1288-1297.

Rainbird, A. L., and A. G. Low. 1986. Effect of various types of dietary fibre on gastric emptying in growing pigs. Br. J. Nutr. $55: 111-121$.

Rapp, C., H. J. Lantzsch, and W. Drochner. 2001. Hydrolysis of phytic acid by intrinsic plant and supplemented microbial phytase (Aspergillus niger) in the stomach and small intestine of minipigs fitted with re-entrant cannulas. J. Anim. Physiol. Anim. Nutr. (Berl.) 85:406-413.

Reddy, N. R., S. K. Sathe, and D. K. Salunkhe. 1982. Phytates in legumes and cereals. Adv. Food Res. 28:1-92.

Rivest, J., J. F. Bernier, and C. Pomar. 2000. A dynamic model of protein digestion in the small intestine of pigs. J. Anim. Sci. 78:328-340.

Rodehutscord, M., M. Faust, and E. Pfeffer. 1999. The course of phosphorus excretion in growing pigs fed continuously increasing phosphorus concentrations after a phosphorus depletion. Arch. Tierernahr. 52:323-334.

Rodehutscord, M., R. Haverkamp, and E. Pfeffer. 1998. Inevitable losses of phosphorus in pigs, estimated from balance data using diets deficient in phosphorus. Arch. Tierernahr. 51:27-38.

Sandberg, A. S., T. Larsen, and B. Sandström. 1993. High dietary calcium level decreases colonic phytate degradation in pigs fed a rapeseed diet. J. Nutr. 123:559-566.

Sands, J. S., D. Ragland, R. N. Dilger, and O. Adeola. 2009. Responses of pigs to Aspergillus niger phytase supplementation of low-protein or high-phytin diets. J. Anim. Sci. 87:2581-2589.
Sauvant, D., J. M. Perez, and G. Tran. 2004. Tables of Composition and Nutritional Value of Feed Materials. Institut National de la Recherche Agronomique, Association Française de Zootechnie, Paris, France.

Sauvant, D., P. Schmidely, and J. J. Daudin. 2005. Les méta-analyses des données expérimentales: Applications en nutrition animale. INRA Prod. Anim. 18:63-73.

Sauvant, D., P. Schmidely, J. J. Daudin, and N. R. St-Pierre. 2008. Meta-analyses of experimental data in animal nutrition. Animal 2:1203-1214.

Schlemmer, U., K. D. Jany, A. Berk, E. Schulz, and G. Rechkemmer. 2001. Degradation of phytate in the gut of pigs - Pathway of gastrointestinal inositol phosphate hydrolysis and enzymes involved. Arch. Anim. Nutr. 55:255-280.

Schulin-Zeuthen, M., E. Kebreab, W. J. J. Gerrits, S. Lopez, M. Z. Fan, R. S. Dias, and J. France. 2007. Meta-analysis of phosphorus balance data from growing pigs. J. Anim. Sci. 85:19531961.

Selle, P. H., A. J. Cowieson, and V. Ravindran. 2009. Consequences of calcium interactions with phytate and phytase for poultry and pigs. Livest. Sci. 124:126-141.

Selle, P. H., and V. Ravindran. 2008. Phytate-degrading enzymes in pig nutrition. Livest. Sci. 113:99-122.

Stein, H. H., C. T. Kadzere, S. W. Kim, and P. S. Miller. 2008. Influence of dietary phosphorus concentration on the digestibility of phosphorus in monocalcium phosphate by growing pigs. J. Anim. Sci. 86:1861-1867.

Strathe, A. B., A. Danfær, and A. Chwalibog. 2008. A dynamic model of digestion and absorption in pigs. Anim. Feed Sci. Technol. 143:328-371.

Taylor, T. G. 1965. The availability of the calcium and phosphorus of plant materials for animals. Proc. Nutr. Soc. 24:105-112.

Theil, H. 1966. Applied Economic Forecasting. Studies in Mathematical and Managerial Economics. North-Holland, Amsterdam, the Netherlands.

Ullah, A. H. J., and D. M. Gibson. 1987. Extracellular phytase (E.C. 3.1.3.8) from Aspergillus ficuum NRRL 3135: Purification and characterization. Prep. Biochem. 17:63-91.

van den Bossche, H. 1999. Devenir du phosphore apporté sur les sols et risques de contamination des eaux de surface. Cas des boues de stations d'épuration. PhD Diss. Univ. de Rennes 1, Rennes, France.

van Milgen, J., A. Valancogne, S. Dubois, J. Y. Dourmad, B. Sève, and J. Noblet. 2008. InraPorc: A model and decision support tool for the nutrition of growing pigs. Anim. Feed Sci. Technol. 143:387-405.

Weaver, J. D., A. H. J. Ullah, K. Sethumadhavan, E. J. Mullaney, and X. G. Lei. 2009. Impact of assay conditions on activity estimate and kinetics comparison of Aspergillus niger PhyA and Escherichia coli AppA2 phytases. J. Agric. Food Chem. 57:5315-5320.

Weremko, D., H. Fandrejewski, T. Zebrowska, K. Han, J. H. Kim, and W. T. Cho. 1997. Bioavailability of phosphorus in feeds of plant origin for pigs (a review). Asian-australas. J. Anim. Sci. $10: 551-566$

Wilfart, A., L. Montagne, H. Simmins, J. Noblet, and J. van Milgen. 2007. Digesta transit in different segments of the gastrointestinal tract of pigs as affected by insoluble fibre supplied by wheat bran. Br. J. Nutr. 98:54-62.

Wise, A. 1983. Dietary factors determining the biological activities of phytate. Nutr. Abstr. Rev. 53:791-806.

Zimmermann, B., H. J. Lantzsch, R. Mosenthin, H. K. Biesalski, and W. Drochner. 2003. Additivity of the effect of cereal and microbial phytases on apparent phosphorus absorption in growing pigs fed diets with marginal $\mathrm{P}$ supply. Anim. Feed Sci. Technol. 104:143-152. 
References

This article cites 77 articles, 18 of which you can access for free at: http://www.journalofanimalscience.org/content/89/11/3596\#BIBL 